\title{
Identifying the Financial Risk Factors of Excessive Indebtedness of Rural Communes in Poland
}

\author{
Aldona Standar ${ }^{1}\left(\mathbb{D}\right.$ and Agnieszka Kozera ${ }^{2, *(D)}$ \\ 1 Department of Economics and Economic Policy in Agribusiness, Faculty of Economics and Social Sciences, \\ University of Life Sciences, Wojska Polskiego 28, 60-637 Poznan, Poland; standar@up.poznan.pl \\ 2 Department of Finance and Accounting, Faculty of Economics and Social Sciences, University of Life \\ Sciences, Wojska Polskiego 28, 60-637 Poznan, Poland \\ * Correspondence: agnieszka.kozera@up.poznan.pl
}

Received: 9 December 2019; Accepted: 18 January 2020; Published: 21 January 2020

check for updates

\begin{abstract}
The purpose of this paper is to identify the financial risk factors of excessive indebtedness of Polish rural communes. The objective of this research task is to verify the following research hypothesis: the main determinant of the risk of excessive indebtedness is the rural communes' own income potential. To meet the objective of this research, an empirical study was carried out in three steps. The first step of the research procedure was the analysis of the operation of Polish rural communes in the context of financial management. In the second step was the analysis of indebtedness of rural communes compared to other types of Polish administrative units in 2007-2017. The evolution of the level and share of total debt in total incomes of entities studied was analyzed, and the share of overindebted rural communes was identified. In the third step, a discriminatory analysis was performed to build a model able to forecast the financial risk factors of excessive indebtedness for Polish rural communes. The problem of increasing indebtedness can be observed in a growing number of communes and on an increasing scale in Poland. The discriminant analysis showed that the share of the operating surplus and own income in total income, as well as the amount of the EU funds per capita (in zlotys), are particularly significant. The study reveals that the smaller the share of the operating surplus in total income is as well as the greater the share of own income in total income and the amount of the EU funds in zlotys per capita are, the lower the value of the estimated discriminatory function is and the higher the risk of excessive indebtedness of a rural commune is.
\end{abstract}

Keywords: communes; excessive indebtedness; financial risk; Poland; discriminant analysis

\section{Introduction}

Along the lines of what is in place in other European countries, Polish government entities handle only a part of local and regional tasks. In accordance with the principle of subsidiarity, the essential part of tasks having no relevance from the countrywide perspective is performed by local government units, namely, local authorities which are subordinate to, and represent the interests of, a local or regional community. Since 1999, a three-level local government model has been in place in Poland, comprising communes, districts, and voivodeships. As basic local government units (LGUs), the communes carry out tasks of importance in the local context while the districts represent an intermediate level in charge of supra-communal tasks. In turn, voivodeships, the largest entities in the country's territorial division, carry out regional tasks.

To perform their tasks and functions, Polish local government entities access defined sources of incomes, i.e., own incomes (including fiscal and non-fiscal income and property income) and transferred incomes (targeted grants and state budget subsidies). The sources and structure of LGU incomes are highly important for the implementation of their financial management tasks and 
policies. LGUs with certain own incomes from precisely defined sources are more autonomous and better positioned to perform their tasks and functions, especially including expensive infrastructural investments. Conversely, a considerable share of transferred incomes (grants, subsidies), largely based on a discretionary allocation of funds by central authorities, restricts the LGUs' financial autonomy. To perform their own tasks, and, in particular, to implement infrastructure investments, local government entities may access repayable sources of finance (including credit and loans).

When considering the basic entities of the Polish local government sector, attention should be paid to rural communes, which represent the largest population of communes (1548 as at 1 November 2018, i.e., over $60 \%$ of all communes). In 2018, over 15 million people lived in rural areas in Poland. Rural communes were inhabited by nearly 11 million people, i.e., as much as $30 \%$ of the total population [1]. The increase in the total number of people inhabiting these areas results from the phenomenon of suburbanisation, which has been observed in recent years. In view of this fact, local communities have growing needs, especially for technical and social infrastructure. According to research carried out by many scientists, including Kozera and Głowicka-Wołoszyn [2], the functional type of many rural communes is transforming from the one characterised by the traditional agricultural function to the type with residential and service-providing functions. At the local level, it is communes that are chiefly burdened with the financial costs of inhabitants' growing needs. In order to implement different projects, rural communes often need to rely on EU funds as their own income is limited. In Poland, the communes' own income potential strictly depends on the functional type they represent. Even though the own income potential of Polish rural communes becomes increasingly higher, it still is the composite result of the demographic potential, local entrepreneurship, and local economic conditions, especially the location rent. As regards many rural communes, low levels of own income potential may be a barrier to socioeconomic development. This is because insufficient incomes make it more difficult to access external funds, whether repayable or non-repayable (including from the EU), which are determinant for the scope of communal investments and local development [3]. As a result, they use repayable sources of financing. By using these funds, rural communes can function under conditions where their income does not correspond to the costs of tasks implemented. Simultaneously, they can maintain high standards of these tasks [4]. The difficult financial situation of local governments has a negative influence on all citizens [5] and economic development in general [6-8]. Excessive indebtedness of local government units, especially the rural communes whose financial independence is below the average level in other administrative types of communes, may lead to the loss of financial liquidity or, in extreme cases, it may even result in falling into a debt spiral [9]. Although according to Polish law, this situation does not result in the bankruptcy of a local government unit, the state takes responsibility for local finance. In view of this fact, it is necessary to apply different measures to prevent the occurrence of this situation. For example, it is necessary to manage the debt adequately and identify the financial risk factors of excessive indebtedness of local government units. Although these actions are not enforced by law, they are the most important aspects of financial management [10]. In international literature, different approaches to debt management procedures are presented, which would be worth looking into. Special attention is paid to the need for a long-term approach to debt management [11-13].

However, a budget deficit cannot be regarded as a purely negative development. Its scale (usually, the relative figures calculated in relation to budget incomes) and, first of all, its reasons must be considered when assessing it [14]. Debt incurred by local government units to finance ongoing expenditure should definitively be judged negatively and is a prohibited practice in certain countries [15]. In accordance with the golden rule for a balanced budget, local government should not undertake liabilities to finance their current tasks.

The risk of indebtedness is affected by factors related with administration, government, law, the economic base of local government units, their general financial situation as well as the amount and character of debt [16]. Kosak-Wojnar and Surówka [17] indicate that the activity of local government units is characterised by the occurrence of different risks, including financial ones, which are related with the methods of financing of the tasks implemented. One of them is the risk of excessive debt. According to Filipiak [18], at present, it is caused not only by the fact that local government units 
implement an increasingly broad spectrum of tasks but also by the consequences of the economic and financial crisis, the decreasing amount of own income. According to Standar [19], the risk is also caused by the implementation of numerous projects co-financed from EU funds.

It should be noted that in the literature worldwide, especially in America, financial risks are understood as economic distress [20], sometimes as fiscal health [21] and fiscal or financial stress [22]. A solution to this problem is greatly influenced by $[23,24]$. First, the problem is that local authorities show little interest in this process. According to Kolha et al. [23], of the 50 states covered by their study, only 15 rely on indicators to monitor the local financial conditions. Many of them use indicators that fail to identify local problems before they become important. The above is related to the next major issue involved in this research topic: the selection of indicators. During her research in 264 municipalities of the Chicago metropolitan area, Handrick [25] found that the analysis of fiscal health is a complex concept whose dimensions, though interlinked, affect each other in an indirect or non-linear manner. This means they must be measured separately rather than being combined into a comprehensive indicator of fiscal standing. Another view is presented by Wang et al. [26] who defined four dimensions of financial condition: dimensions in cash, budget, long-run and service-level solvencies, and 11 financial condition indicators. In turn, Jones and Walker [24] proved the existence of a relationship between incomes and population, on one side, and the emergence of fiscal hazards, on the other. In the relevant literature, the third important aspect is tackled by Rivenbark and Roenigk [27]. They noted the importance of the decision to analyze, interpret, and present the financial condition to selected officials and to see what management practices help in the analysis of financial conditions. The recent interest in the issue of the financial risk of communes has increased, as evidenced by recent research in all the world, e.g., in China—[28], in Hungary—[29], in Spain—[30], in Poland - [31].

The purpose of this paper is to identify the financial risk factors of excessive indebtedness of Polish rural communes. The objective of this research task is to verify the following research hypothesis: the main determinant of the risk of excessive indebtedness is the rural communes' own income potential. To meet the objective of this research, the empirical study was carried out in three steps. The first step of the research procedure was the analysis of the operation of Polish rural communes in the context of financial management. In the second step was the analysis of indebtedness of rural communes compared to other types of Polish administrative units in 2007-2017. The evolution of the level and share of total debt in total incomes of entities studied was analysed, and the share of overindebted rural communes was identified. In the third step, a discriminatory analysis was performed to build a model able to forecast the financial risk factors of excessive indebtedness for Polish rural communes.

This paper addresses the issues of public debt, which, in the theoretical sense, are a part of general economic and public finance theories. Generally, there are two conflicting doctrines regarding debt. According to the orthodox doctrine, debt is the consequence of defective financial management. In turn, the interventionist doctrine claims that debt should be viewed as a positive development which stimulates economic growth and makes investments financially feasible [16].

\section{Materials and Methods}

The empirical research was based on the database published by the Ministry of Finance [32] and the Central Statistical Office of Poland [1]. The results are presented in Polish currency (the key data was converted to euro as per the weighted average exchange rate of the National Bank of Poland, which was from 3.52 EUR/PLN to 4.36 EUR/PLN [33]). In the first part of the research, basic methods of descriptive statistics were used to process the empirical data collected from the database so as to analyse the indebtedness of rural communes in Poland. The results were shown in boxplots. Tukey [34] introduced the boxplot to exploratory data analysis. In the third part of the research, discriminant analysis was used to build a model enabling prediction of excessive indebtedness of rural communes and identification of chief financial factors causing the risk of excessive indebtedness of these entities. This method was selected following a literature study and an attempt to build other models, e.g., a logit model, which, however, failed to deliver satisfactory results for the discriminant analysis. 
Discriminant analysis is a classification method that is categorised as both a method of multidimensional statistical analysis and as a taxonomic method [35]. It is used for ordering and classification of economic and financial phenomena according to many explanatory variables at the same time [36-38]. Several assumptions needed to be verified in order to use this analysis. While the variables should follow a normal distribution, the discriminatory analysis is tolerant to a moderate violation of this assumption in the case of large samples. The model was built using Statistica software which checks the tolerance value $[39,40]$. Should that principle be violated, a wrong matrix message will be displayed, making it impossible to continue the analysis. The next assumption is about the sample size. In this case, the number of variables is adequate for the number of cases [40]. Because the discriminatory analysis is highly sensitive to outliers, the variables were scanned for outlying observations, which were subsequently removed.

There are different methods for undertaking discriminant analysis. The most common linear function was used to estimate the form of the discriminant model [41]:

where:

$$
Z_{l j}=\beta_{o}+\beta_{1} X_{1}+\ldots+\beta_{k} X_{k}
$$

$Z_{l j}$-dependent variable for $j$-th item $(j=1,2, \ldots, n)$ in $l$-th class (excessive debt-yes/no);

$\beta_{0}$-discriminant function constant;

$\beta_{1}, \ldots, \beta_{k}$-discriminant function coefficients $(i=1,2, \ldots, k)$;

$X_{1}, \ldots, X_{k}$-explanatory variables $(i=1,2, \ldots, k)$.

The objects under study are classified according to the estimated function value, which is usually a combination of several financial indicators (cf. $[40,42,43]$, which clearly differentiate (discriminate) the collection of items. In order to allocate an item under study to a particular group, the discriminant function value of the total value of products of variables and function parameters (i.e., the indicators' weights) is compared with the limit value $[44,45]$.

The discriminant function is a basic tool used in discriminant analysis. When adequate explanatory variables are selected, the function can be used to allocate an item (e.g., a commune) to a particular group of items $[44,46]$. As far as the prediction of financial factors causing the risk excessive indebtedness of local government units is concerned, discriminant analysis can be used to divide the rural communes under study into two separate classes: 0 and 1, referring to the communes unthreatened or threatened by the risk of excessive debt (dependent variable). The main period covered by the discriminatory model is 2012 to 2014. It was selected purposely because a large number of rural communes experienced debt problems at that time. This situation was preceded by the public finance crisis, which had reduced their incomes while intensifying pressure on the communes to make investments co-financed with available EU funds. Two subsequent discriminative models for the periods 2007-2009 and 2015-2017 were developed in order to carry out a comparative analysis of the main financial factors behind excessive indebtedness of Polish rural communes.

In our research, the rural communes, during the three years, where the average share of the total debt in the total income was greater than $50 \%$, were classified as the communes with excessive debt. The authors of this paper defined the excessive indebtedness threshold as a situation where the ratio of total liabilities to total income is $50 \%$. Until the end of 2013 , the total liabilities/total income ratio was the official indebtedness indicator, and could not exceed $60 \%$ [47]. The authors set a more restrictive level because even a ratio of 50\% meant financial problems for local government units. First of all, communes with such a high ratio of debt to total income had a poor credit rating, restricting their ability to access repayable instruments (loans). Secondly, local government authorities with a lower financial rating often relied on shadow-banking loans whose high interest rates posed a considerable risk of sending them into a debt spiral in the next years. What also needs to be emphasized is that even at the same level of debt (numerator), the ratio can vary in function of fluctuations in total income (denominator), which could drive a further several percentage point increase in the ratio, resulting in the commune going beyond the defined threshold.

A set of 18 financial indicators was used as explanatory variables showing the financial situation and functioning of the local government units under study. They served as predictors of the risk 
of excessive indebtedness of local government units. The indicators recommended by the Ministry of Finance and by experts in local finance [48] were selected (later in this paper, you may find the characteristics of indicators taken into consideration when building the discriminatory model). The selection was also based on an overview of the literature and previous studies concerning the forecasting of the financial threat of local government units (cf. [43]). The variables were calculated as average values (medians) for three-year periods and they characterised the financial condition of local government units, especially referring to the financial independence and attractiveness of these entities. The time frames of this study were selected purposely because, as mentioned earlier, the communes considered reported the highest levels of debt at that time, translating into a risk of excessive indebtedness. Having made the substantive selection of discriminant variables, they were statistically verified. As a result of conducted statistical verification, due to a high correlation with the other variables, eight variables were eliminated from further analysis. In consequence, the model was based on the following ten variables (financial indicators) characterised by high discriminatory power:

- share of own incomes in total incomes $(\%, O I / T I)$ which reflects the financial independence from the state budget and financial autonomy (the higher the ratio, the greater the local government's financial autonomy);

- the share of property (investment) expenditures in total incomes (\%, PE/TI) showing the scale of investments in relation to the entity's income potential (the higher the ratio, the greater the focus on development);

- share of remunerations and related expenditure in current expenditure $(\%, R / C E)$, a ratio which shows the proportion between personnel costs and in-kind expenses, and therefore tells whether the incomes are distributed properly;

- the level of property (investment) expenditure per capita in PLN (PE/M) showing the LGU's investment potential per inhabitant;

- fiscal wealth indicator per capita (in zlotys, $F W I$ ) —-the indicator shows the commune's income potential, which is decisive to the economic power of local government units (The expenditure capacity is determined especially by the amount of income from local taxes received by the commune (agricultural tax, forest tax, property tax, vehicle tax, tax on civil law transactions, tax from the tax card income, income from the exploitation fee), which indicates the scale of an entity's fiscal wealth [49]);

- the level of income from income taxes which are state budget incomes in PLN per capita (IT/M), reflecting the residential and economic attractiveness of the LGU (the higher the ratio, the greater the financial autonomy of the local government);

- the amount of EU funds accessed in PLN per capita (EU/M), showing the activity and effectiveness of local authorities in accessing additional investment funds;

- the operating surplus in PLN per capita $(O S / M)$, reflecting the financial standing of the commune: its capacity to invest and incur debt;

- the share of operating surplus in total incomes $(\%, O S / T I)$, showing the part of the total income potential accounted for by investment funds obtained primarily in the form of investment grants and savings from the current part of the budget;

- self-financing ratio (SFR) - the ratio refers to the share of operating surplus and property income in property expenditures. It indicates the extent to which a local government unit finances investments with its own funds, i.e., the financing capacity. The higher the ratio is, the lesser is the risk of losing financial liquidity due to excessive debt service costs. However, on the other hand, if the ratio is high, it may also indicate a low implementation of investments in relation to the potential of a particular local government unit.

Afterwards, the selected explanatory variables were standardized. Outliers (extreme values) were eliminated from the data set, as they could considerably affect the results of research. As a consequence, upon removal of outliers, 140 rural communes were found to be overindebted in 2012-2014. Thus, the main 
discriminant model was based on 280 rural communes split into two equal groups. Group 1 consisted of 140 communes with a ratio of total debt to total incomes beyond 50\%; Group 2 was composed of 140 randomly selected communes which did not exhibit overindebtedness in the study period.

\section{Results and Discussion}

\subsection{Functioning of Polish Rural Communes}

Ever since Poland joined the European structures, much attention has been paid to rural development [49-51], also in the context of assessing the financial condition of rural areas, including excessive indebtedness [52-55]. Research carried out under the Socioeconomic Development of Rural Areas in Poland project by the Institute of Rural and Agriculture Development [56] and by the Foundation for the Development of Polish Agriculture [57] is of particular importance in this regard. The role of rural areas in the national economy is reflected by their area and population (as they make up over $90 \%$ of the national territory and are home to over $30 \%$ of the total population) [1].

Three administrative types of Polish basic local government units can be identified: urban communes (whose borders coincide with the limits of the commune capital city), rural communes (which do not include any cities) and urban-rural communes (which include both cities within their administrative boundaries and territories located beyond city limits). In 2017, there were 2478 communes, of which rural units (over $60 \%$ of the total number) and urban units (barely 13\%) formed the largest and the smallest group, respectively [1]. The basic functions of rural communes continue to be related to agriculture. However, the ongoing processes and developments, including the increasing demographic and economic potential of rural areas (especially those located near big cities, i.e., metropolitan areas), contribute to changing the nature of functions fulfilled by rural areas. Indeed, many of them shift from a typical agricultural function towards a residential and service functional type [2]. At the same time, the needs of the local community keep growing, including in the area of technical and social infrastructure; and it is largely the responsibility of local government units to implement the relevant investments.

In Poland, the operational framework for financial management of local government units is provided in several documents, including the Constitution of the Republic of Poland [58], the Public Finance Act [59] and the Act on Incomes of Local Government Units [60]. In turn, the scope of municipal government activities is set forth in the Municipal Government Act [61] and the European Charter of Local Self-Government [62]. The foundation for municipal operations is the capacity to generate income and the ability and possibility to obtain revenue in an amount necessary to finance the needs of the local community. The European Charter of Local Self-Government (Article 9) [62] grants the right to sufficient own financial resources and the freedom to allocate them. Also, it specifies that the financial resources of local communities should be proportional to their competence, i.e., to the extent of tasks carried out by the local government. What matters from the perspective of communes is the guarantee that any changes in their tasks and competencies shall be accompanied by corresponding changes in the delivery and redistribution of dedicated funds [63].

Own income potential of municipal government units (which includes most sources of own incomes) is one of the drivers of stable local development. Own incomes of entities active in the local government sector are incomes that involve fiscal sovereignty and ownership of specific sources of income or the authority to introduce and develop specific incomes. In turn, as provided for in the Constitution of the Republic of Poland, own incomes of LGUs are incomes other than general subsidies and targeted grants from the state budget. In this sense, own incomes of LGUs also include incomes derived from their share in collected income taxes (personal income and corporate income taxes) which are state budgetary income. This is the very category of income which puts the LGUs in a position to make changes, including improving the development level of the socioeconomic infrastructure, enhancing innovativeness, and providing the local community with better conditions and standards of living. Own incomes of Polish communes mainly include local taxes and fees (e.g., property tax, agricultural tax, forestry tax), income taxes and funds derived from the sale and lease of property. At 
the same time, the amount of own incomes per capita and their share in total incomes are among the main indicators of these units' financial autonomy [63-67].

In Poland, urban communes have by far the highest level of own incomes, which amounted to PLN 96.4 billion (EUR 22.6 billion) in 2017, i.e., PLN 320 million per commune (EUR 75.2 million). Because of their high demographic and economic potential, urban communes, especially big cities (metropolises), accumulate a large part of the total own incomes of communes. In absolute terms, rural communes have a distinctively small own income potential. In 2017, their total own income totaled barely PLN 18 billion (EUR 4.2 billion), which is only PLN 12 million per commune (EUR 2.8 million). Between 2007 and 2017, an enhancement was observed in the own income potential of basic Polish LGUs. The greatest increase in own incomes (by more than 95\%) was found in rural communes; this could have been caused by the benefits they derive from suburbanization. Indeed, this process drives an increase in the demographic and economic potential of rural communes. As a consequence, many of them shift to another functional type which, in turn, translates into much greater tax revenues (Table 1).

Table 1. Selected indicators of financial management in Polish communes in 2007-2017.

\begin{tabular}{|c|c|c|c|c|c|c|c|c|c|c|c|}
\hline Specification & 2007 & 2008 & 2009 & 2010 & 2011 & 2012 & 2013 & 2014 & 2015 & 2016 & 2017 \\
\hline \multicolumn{12}{|c|}{ Level of own income in million PLN } \\
\hline total & $57,337.3$ & $65,063.2$ & $63,284.0$ & $66,548.2$ & $70,441.7$ & $73,930.5$ & $78,604.8$ & $84,604.7$ & $88,347.0$ & $91,003.8$ & $96,388.9$ \\
\hline urban & $39,188.2$ & $43,932.8$ & $42,461.0$ & $43,988.7$ & $46,112.3$ & $47,945.2$ & $50,868.8$ & $54,535.7$ & $56,702.7$ & $58,383.3$ & $61,543.6$ \\
\hline urban-rural & 9019.1 & $10,514.6$ & $10,348.0$ & $11,130.6$ & $11,982.2$ & $12,717.5$ & $13,468.9$ & $14,534.9$ & $15,192.1$ & $15,835.1$ & $16,965.6$ \\
\hline rural & 9130.0 & $10,615.9$ & $10,475.0$ & $11,428.9$ & $12,347.2$ & $13,267.9$ & $14,267.1$ & $15,534.1$ & $16,452.2$ & $16,785.5$ & $17,879.7$ \\
\hline \multicolumn{12}{|c|}{ Level of own income level in PLN per capita } \\
\hline total & 1504.3 & 1707.0 & 1658.7 & 1727.8 & 1828.4 & 1918.6 & 2041.6 & 2198.4 & 2297.4 & 2368.3 & 2508.7 \\
\hline urban & 2074.7 & 2332.8 & 2258.1 & 2333.1 & 2450.4 & 2552.8 & 2716.5 & 2920.5 & 3043.4 & 3142.8 & 3317.6 \\
\hline urban-rural & 1063.2 & 1234.1 & 1205.7 & 1271.0 & 1361.7 & 1444.3 & 1530.1 & 1643.7 & 1713.7 & 1779.5 & 1898.0 \\
\hline rural & 849.7 & 986.3 & 972.9 & 1048.1 & 1131.9 & 1212.1 & 1300.1 & 1416.3 & 1501.4 & 1532.7 & 1635.4 \\
\hline \multicolumn{12}{|c|}{ Share of own income in total income (\%) } \\
\hline total & 55.2 & 58.2 & 54.9 & 52.7 & 53.1 & 52.9 & 54.5 & 55.4 & 55.8 & 51.6 & 50.8 \\
\hline urban & 64.8 & 68.5 & 65.1 & 62.5 & 62.2 & 60.8 & 62.0 & 62.5 & 62.9 & 60.1 & 59.7 \\
\hline urban-rural & 48.1 & 51.0 & 48.0 & 46.5 & 47.4 & 48.3 & 50.1 & 51.1 & 51.3 & 45.7 & 44.6 \\
\hline rural & 37.1 & 39.3 & 36.8 & 35.9 & 37.1 & 38.5 & 40.3 & 41.9 & 42.7 & 37.8 & 36.8 \\
\hline \multicolumn{12}{|c|}{ Level of investment expenditure in PLN per capita } \\
\hline total & 530.7 & 621.2 & 729.9 & 840.6 & 785.9 & 673.7 & 631.6 & 747.7 & 687.4 & 477.8 & 662.8 \\
\hline urban & 654.0 & 754.2 & 839.1 & 893.3 & 856.0 & 800.5 & 743.9 & 888.9 & 806.3 & 536.8 & 685.0 \\
\hline urban-rural & 388.8 & 480.0 & 597.8 & 718.1 & 666.0 & 528.0 & 476.8 & 559.3 & 528.1 & 400.4 & 598.4 \\
\hline rural & 426.7 & 500.8 & 644.8 & 848.0 & 761.9 & 573.9 & 564.9 & 659.6 & 614.4 & 440.7 & 677.8 \\
\hline \multicolumn{12}{|c|}{ Financial result in million PLN (surplus / budget deficit) } \\
\hline total & 1925.3 & -2303.4 & $-1,0994.1$ & $-1,2498.7$ & -8506.9 & -2567.7 & -135.1 & -1922.8 & 2458.8 & 6098.4 & -769.7 \\
\hline urban & 1366.9 & -1915.1 & -7484.0 & -6544.8 & -5372.8 & -2701.5 & -567.6 & -1349.5 & 1014.8 & 3266.5 & -179.8 \\
\hline urban-rural & 207.8 & -323.9 & -1791.0 & -2517.6 & -1399.1 & -122.6 & 93.6 & -189.7 & 511.6 & 1198.2 & -298.7 \\
\hline rural & 350.6 & -64.4 & -1719.0 & -3436.3 & -1735.0 & 256.4 & 338.9 & -383.5 & 932.3 & 1633.7 & -291.2 \\
\hline \multicolumn{12}{|c|}{ Relation of budget deficit to realised investment expenditure (\%) } \\
\hline total & $\times$ & 9.7 & 39.5 & 38.6 & 28.1 & 9.9 & 0.6 & 6.7 & $x$ & $\times$ & 3.0 \\
\hline urban & $x$ & 13.5 & 47.5 & 38.9 & 33.4 & 18.0 & 4.1 & 8.1 & $\times$ & $\times$ & 1.4 \\
\hline urban-rural & $x$ & 7.9 & 34.9 & 40.0 & 23.9 & 2.6 & $\times$ & 3.8 & $\times$ & $x$ & 5.6 \\
\hline rural & $x$ & 1.2 & 24.7 & 37.1 & 20.8 & $\times$ & $\times$ & 5.3 & $\times$ & $x$ & 3.9 \\
\hline
\end{tabular}

Polish rural communes are characterized by the smallest own income potential per capita. They are mostly agricultural in nature, which results in low levels of income derived from property tax, personal income tax and corporate income tax; note that these are the main sources of own incomes for urban units. In 2017, own incomes collected by rural communes averaged at PLN 1635 per capita (284 EURO), i.e., over $60 \%$ less than in urban communes. In addition to having the smallest own income potential per capita, rural communes also prove to be the most heterogeneous in this regard (Table 1).

Note also that rural communes report the smallest financial autonomy, quantified with the share of own incomes in total incomes. In 2017, in rural communes, the share of own incomes in total incomes was barely $37 \%$, compared to over $50 \%$ for an average municipality. Irrespective of the administrative type of territorial units covered by this study, a smaller share of own incomes in their total incomes 
may be observed in 2009-2010 and in 2016-2017. In the first period, the reduced share of own incomes in total incomes (which means a decline in the levels of financial autonomy) resulted from smaller amounts of taxes being levied to finance the municipal budgets; but in 2016-2017, the tax receipts were growing. Therefore, the reduction in the contribution of own incomes to total incomes of the LGUs under consideration was the consequence of larger budgetary incomes drawn from non-fiscal sources. Indeed, transfer incomes from the state budget (mainly including targeted grants allocated to delegated tasks) have grown considerably since 2016. This is because the benefits under the Rodzina 500+ program (put in place in Poland in 2016 to support large families) are disbursed through the municipal budget. The extent of this support measure is so large that it prevents the proper interpretation of the indicator discussed. Therefore, when analyzing the decreasing level of own incomes in total incomes, it must be benchmarked against the increasing level of own incomes per capita. The above means that the financial autonomy of basic Polish LGUs does not decline [67].

LGUs must invest in order to ensure economic development within their territories. In Poland, local government units make up a considerable part of economic processes. As part of their own tasks, they take investment measures to improve the conditions and standards of living for the population through development processes and improvements to technical and social infrastructure. Measures are also taken to attract capital, which stimulates the creation of new jobs. In relative terms, the biggest investment expenditure is incurred by urban communes, especially in urban districts and in the largest ones (metropolises). In 2017, investment expenditure incurred by urban communes was PLN 685 per capita (EUR 180.9), compared to PLN 678 per capita (EUR 159.2) in rural communes. According to Dolewka [68] and a number of other researchers, practice demonstrated that big cities allocate greater financial resources to infrastructural development; this results from a different scale of needs which are primarily caused by the number of residents. Although rural communes have a smaller investment potential than other municipality types, they recorded the highest growth in investments over the study period. However, the increase in investment expenditure resulted in a greater budget deficit; that trend prevailed in municipal government units practically throughout the period covered by this study (Table 1).

Undoubtedly, the global economic crisis which occurred during the study period had an adverse effect on the budgetary performance of Polish communes. Indeed, the local finance crisis resulted in decreasing the level of own income potential of all local government units. A study by Kozera [69] suggests that over $60 \%$ of rural communes experienced a clear reduction in own incomes between 2008 and 2009. The decline in own incomes of rural communes was especially due to income streams, which depend on the economic situation, primarily including incomes derived from the share in personal and corporate income taxes. It perpetuated the fiscal imbalance manifested through growing budget deficits and the deteriorating operational performance (reduction in the operating surplus or increase in operational deficit). The rapid decline in financial performance in both rural and other types of communes was observed in 2009-2011. At that time, their total budget deficit reached the peak level. Rural communes recorded the highest budget deficit (a total of PLN 3436.3 million-EUR 860.2) in 2010. In 2009-2011, a budget deficit was reported by $70 \%$ of all rural communes [30]. However, the way the funds derived from the deficit are spent sometimes fails to comply with that rule. When analyzing the ratio between the budget deficit and investment expenditure of Polish communes, it can be noticed that peak levels were recorded in 2009-2011. The average budget deficit/investment expenditure ratio was nearly $25 \%$ in 2009 and went up to over $37 \%$ in 2010 (Table 1).

\subsection{The Indebtedness in Poland between 2007 and 2017}

Today, public debt is a problem faced by most market economy countries. That economic category is commonly defined as total financial liabilities of public authorities caused by the excess of expenditure over income. Recently, the world has experienced a sharp increase in public debt levels. In the 1990s, public debt was also recorded in economies in transition, including Poland. This was the consequence of public finance disruptions that accompanied the economic transformation. In recent years the financial and economic crisis resulted in serious challenges being posed to many European governments [70]. 
In the study period (2007-2017), the average level of public debt expressed as a percentage of GDP went up from $61.7 \%$ to $82.1 \%$ in European Union countries. When comparing the 2007 and 2017 figures, note that only three countries (Malta, Denmark and Bulgaria) recorded a decline in debt levels. It was the opposite in other countries, especially in Greece, Portugal and Spain which are among the most indebted economies. In Poland, the debt/GDP ratio in 2007 and 2017 was 45\% and 50.6\%, respectively. This is a safe level because, in accordance with national and Union legislation, the state-level public debt ratio cannot exceed $60 \%$ [71].

When comparing the levels of state-level public debt in Poland between 2017 and 2007, note that it grew by over 82\%, from PLN 527.4 billion to PLN 961.9 billion (from EUR 139.4 billion to EUR 225.9 billion). Of the three sectors that generate state-level public debt, the government sector had the greatest contribution; in the study period, it varied in the range of $94.8 \%$ (2007) to $92.8 \%$ (2017) of total state debt. Its decreasing importance in the debt structure results from the fact that local government debt grows at a faster rate. In 2007, that sector accounted for PLN 24.5 billion (EUR 6.5 billion) of debt (4.9\% of state-level public debt) and reached as much as PLN 69.5 billion (EUR 16.3 billion) (7.8\% of state-level public debt) in 2017. When comparing the growth rates between the sectors considered, it can be noticed that local government debt grew quickest (and nearly doubled) whereas government debt grew by a half and social insurance debt decreased by $96 \%$ as a result of open pension funds being transferred to the Social Insurance Institution. It needs to be emphasized that local government debt reached the highest level (PLN 60-70 billion-EUR 14.5-16.7 billion) in 2011-2015, contributing 8-9\% to state-level public debt (Table 2).

Table 2. Level and structure of state-level public debt in Poland by sectors in 2007-2017.

\begin{tabular}{|c|c|c|c|c|c|c|c|c|c|c|c|}
\hline Sector & 2007 & 2008 & 2009 & 2010 & 2011 & 2012 & 2013 & 2014 & 2015 & 2016 & 2017 \\
\hline & \multicolumn{11}{|c|}{ The level of public debt (in billion PLN) } \\
\hline Government & 500.2 & 566.9 & 623.6 & 692.4 & 748.8 & 770.8 & 813.5 & 755.0 & 805.1 & 895.6 & 892.3 \\
\hline Local government & 24.5 & 28.1 & 39.3 & 53.5 & 64.3 & 67.4 & 68.4 & 71.7 & 72.1 & 69.6 & 69.5 \\
\hline of which communes & 10.0 & 10.8 & 14.6 & 21.9 & 26.0 & 26.2 & 25.8 & 26.4 & 25.4 & 23.9 & 24.9 \\
\hline Social security & 2.7 & 2.8 & 7.0 & 2.0 & 2.3 & 2.3 & 0.4 & 0.1 & 0.1 & 0.1 & 0.1 \\
\hline \multirow[t]{2}{*}{ Total } & 527.4 & 597.8 & 669.9 & 747.9 & 815.4 & 840.5 & 882.3 & 826.8 & 877.3 & 965.3 & 961.9 \\
\hline & \multicolumn{11}{|c|}{ The structure of public debt (\%) } \\
\hline Goverment & 94.8 & 94.8 & 93.1 & 92.6 & 91.8 & 91.7 & 92.2 & 91.3 & 91.8 & 92.8 & 92.8 \\
\hline $\begin{array}{l}\text { Local goverment } \\
\text { of which communes }\end{array}$ & 4.9 & 5.0 & 6.3 & 7.7 & 8.6 & 8.7 & 8.4 & 9.5 & 9.0 & 7.8 & 7.8 \\
\hline as $\%$ local goverment & 40.8 & 38.4 & 37.2 & 40.9 & 40.4 & 38.9 & 37.7 & 36.8 & 35.2 & 34.3 & 35.8 \\
\hline as $\%$ total & 1.9 & 1.8 & 2.2 & 2.9 & 3.2 & 3.1 & 2.9 & 3.2 & 2.9 & 2.5 & 2.6 \\
\hline Social security & 0.5 & 0.5 & 1.0 & 0.3 & 0.3 & 0.3 & 0.0 & 0.0 & 0.0 & 0.0 & 0.0 \\
\hline
\end{tabular}

The level and growth of local government debt were heavily impacted by debt generated by communes, Polish basic LGUs. From 2007 to 2017, municipal debt grew by PLN 14.9 billion (EUR 3.5 billion), i.e., one-and-a-half times. Considering the individual components of local government debts, municipal debt had the largest share, varying in the range of $40.8 \%$ in 2007 to $35.8 \%$ in 2017 . Although it moved down in the structure of local government debt (the indebtedness of other LGUs grew at a faster rate), its share in the structure of total debt increased (Table 2).

\subsection{The Indebtedness of Rural Communes in Poland between 2007 and 2017}

Polish law imposes restrictions on debt levels. They result not only from decisions made by national authorities but also from international agreements (Poland signed the fiscal compact in 2013) and membership in integration groupings (Poland joined the European Union in 2004). Pursuant to a provision of Chapter X of the Constitution of the Republic of Poland, it is prohibited to raise loans or to provide guarantees as a consequence of which the government debt would exceed $3 / 5(60 \%)$ of GDP (Article 216, Para. 5 [58]). The debt ratios are also regulated under the Public Finance Act. It primarily imposes some restrictions on the way the LGUs may enter into commitments, and provides for prudence and recovery procedures applicable to entities of the public finance sector if the ratio of government debt to GDP (and the ratio to GDP of the amount resulting from the conversion of 
government debt to the Polish currency based on the arithmetic mean of average currency exchange rates published by the National Bank of Poland within a budget year, in the case of debt expressed in foreign currencies), less spare funds of the Ministry of Finance, exceeds 55\% [75]. Until the end of 2013, the indebtedness of communes was limited by the ratio of total debt to total incomes (Article 170 [46]). From 1 January 2014, the debt incurred within a year cannot exceed the average operating surplus from the last three years (Article 243 [59]). The new debt indicator is an individual restriction for local government units. It is particularly beneficial to local governments with a large income potential that translates into a strong collateral for loans. In turn, the indicator previously used as a debt limit (ratio of total liabilities to total income) offers a very important advantage: it allows us to compare the figures between different local government units, and therefore the Ministry of Finance continues to present it as one of key yardsticks of financial condition of LGUs. As a consequence, the total liabilities/total income ratio is the one used in this paper as an indicator of indebtedness.

Communes are basic local government units. They implement the largest number of public tasks assigned to the entities of the local government sector in Poland. We can distinguish between three administrative types of communes: urban, rural and urban-rural communes. Rural communes are the largest group because they make more than $60 \%$ of the total number of communes in Poland and they are the most diversified group of commune governments among all administrative types. These communes are characterised not only by their fundamental agricultural function but also, especially in recent years, they have been losing this function in favour of the service-providing and residential functions, which are characteristic of other administrative types. Due to the progressing suburbanisation processes, they are the most convenient places to live and run a business. Thus, they are becoming a residential, production and logistic base. On the other hand, communes with natural values are often transformed into specialised centres of tourism and recreation. In communes with natural resources, the development of other than the industrial function usually does not make sense. The industry often becomes the main source of income for the local community. The change in the significance and role of rural communes results in a larger number of investments adjusted to the needs of new inhabitants, investors and tourists. The implementation of these tasks requires considerable funds. On the one hand, the authorities of communes feel the competitive pressure of other local governments. On the other hand, they feel that they have a unique opportunity to use the EU funds and make numerous capital-intensive investments with a minimal amount of their own funds. In order to create local development and increase the attractiveness of rural areas for residential and business investments, the authorities of communes use all possible financial sources. They increasingly tend to use repayable sources.

Rural communes increasingly use repayable funds to implement investments. This fact is proven by the change in the average amount of total liabilities per capita (Table 3). From one year to another, the average value (median) of this indicator has been increasing in the local governments under study. It rose from 268 zlotys (EUR 71) in 2007 to 898 zlotys (EUR 218) per capita in 2011 (i.e., by 227\%). Then it slightly decreased to 751.9 zlotys (EUR 205) per capita in 2017 (i.e., by 4\%). It is necessary to note that during the entire period under study, in rural communes, the median of the total debt per capita in zlotys was lower than in urban-rural communes or in urban ones. It is noteworthy that there was not only an increase in the total debt of rural governments but also we could observe increasing differences between entities in the amount of their debt due to the growing number of communes with excessive amounts of debt. In 2011, when this indicator reached the greatest value, there were 239 communes where the debt per capita exceeded 1500 zlotys (EUR 264). In the commune of Rewal, the indicator amounted to 6400 zlotys (EUR 1553) per capita. In 2017, 235 communes exceeded the limit of 1500 zlotys. In the commune of Ostrowice, the debt per capita exceeded 18,000 zlotys (EUR 3106), whereas in the commune of Rewal, it exceeded 14,000 zlotys (EUR 8841) [32]. 
Table 3. The level of total liabilities of communes classified according to the administrative type in Poland between 2007 and 2017 (\%).

\begin{tabular}{|c|c|c|c|c|c|c|c|c|c|c|c|}
\hline \multirow{2}{*}{ Specification } & \multicolumn{11}{|c|}{ Debt per Capita (in Zlotys) } \\
\hline & 2007 & 2008 & 2009 & 2010 & 2011 & 2012 & 2013 & 2014 & 2015 & 2016 & 2017 \\
\hline \multicolumn{12}{|c|}{ Median } \\
\hline total & 312.5 & 311.6 & 448.7 & 799.2 & 948.9 & 939.1 & 921.4 & 929.7 & 764.5 & 706.5 & 734.7 \\
\hline urban & 426.9 & 439.3 & 622.9 & 859.9 & 983.3 & 997.3 & 1012.0 & 1021.6 & 935.0 & 855.5 & 870.0 \\
\hline urban-rural & 392.9 & 400.6 & 559.9 & 900,9 & 1060.5 & 1049.7 & 1038.2 & 1064.7 & 994.5 & 922.5 & 963.0 \\
\hline rural & 267.7 & 267.7 & 368.6 & 739.5 & 897.8 & 873.5 & 846.2 & 859.1 & 774.2 & 706.0 & 751.9 \\
\hline \multicolumn{12}{|c|}{ Range } \\
\hline total & 2570.3 & 4264.9 & 7161.9 & 6408.5 & 6414.3 & 7951.8 & $35,603.7$ & $37,434.5$ & $36,962.0$ & $30,241.1$ & $20,038.6$ \\
\hline urban & 2570.3 & 1815.4 & 2269.3 & 3090.9 & 4066.4 & 4610.3 & 4422.6 & 5576.3 & 3767.9 & 2720.2 & 3972.8 \\
\hline urban-rural & 2415.4 & 2566.5 & 3052.5 & 3110.8 & 3998.5 & 3428.1 & 4220.5 & 4688.0 & 5544.5 & 5321.0 & $12,130.5$ \\
\hline rural & 2136.2 & 4264.9 & 7161.9 & 6408.5 & 6414.3 & 7951.8 & $35,603.7$ & $37,434.5$ & $36,220.0$ & $30,172,5$ & $18,676.2$ \\
\hline \multicolumn{12}{|c|}{ Coefficient of variation * $(\%)$} \\
\hline total & 61.4 & 69.4 & 61.7 & 42.3 & 39.6 & 40.8 & 40.7 & 41.6 & 55.9 & 57.2 & 58.1 \\
\hline urban & 46.2 & 45.8 & 38.8 & 31.1 & 32.4 & 33.7 & 28.3 & 25.0 & 30.3 & 34.7 & 38.1 \\
\hline urban-rural & 45.9 & 57.1 & 47.9 & 33.1 & 30.9 & 32.6 & 32.9 & 35.5 & 40.2 & 43.9 & 41.8 \\
\hline rural & 65.8 & 75.9 & 74.0 & 48.9 & 43.7 & 45.9 & 46.6 & 47.0 & 52.3 & 56.3 & 55.5 \\
\hline \multicolumn{12}{|c|}{ Number of communes with debt per capita exceeding 1500 zlotys } \\
\hline Total & 15 & 19 & 53 & 218 & 379 & 408 & 353 & 433 & 382 & 334 & 404 \\
\hline urban & 2 & 3 & 6 & 24 & 33 & 36 & 27 & 39 & 35 & 32 & 36 \\
\hline urban-rural & 4 & 5 & 19 & 60 & 107 & 124 & 108 & 131 & 131 & 115 & 133 \\
\hline rural & 9 & 11 & 28 & 134 & 239 & 248 & 218 & 263 & 216 & 187 & 235 \\
\hline
\end{tabular}

*: positional measure. Source: the authors' compilation based on data published by the Ministry of Finance [32]. 
The overall increase in the amount of communes' debt resulted in an increase in the average share of total liabilities in total income. Until the end of $2013,60 \%$ was the maximum limit allowed by law [32,46]. Until 2011, the median of this indicator was increasing in local government units (Table 3, Figure 1). Also the range between the maximum and minimum value of the share of total liabilities in the total income of communes was increasing systematically. In 2007, the maximum amount of debt exceeded the statutory limit only by $5 \%$, but in 2017 , it exceeded the limit by over seven times. It shows that there is a growing number of communes facing the problem of increasing indebtedness.

Liabilities per capita in PLN

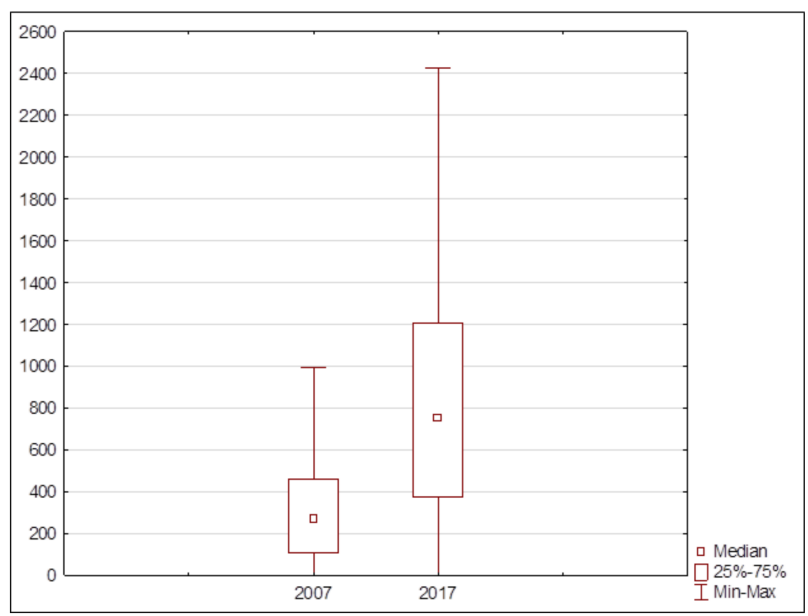

Share of total liabilities in total income (\%)

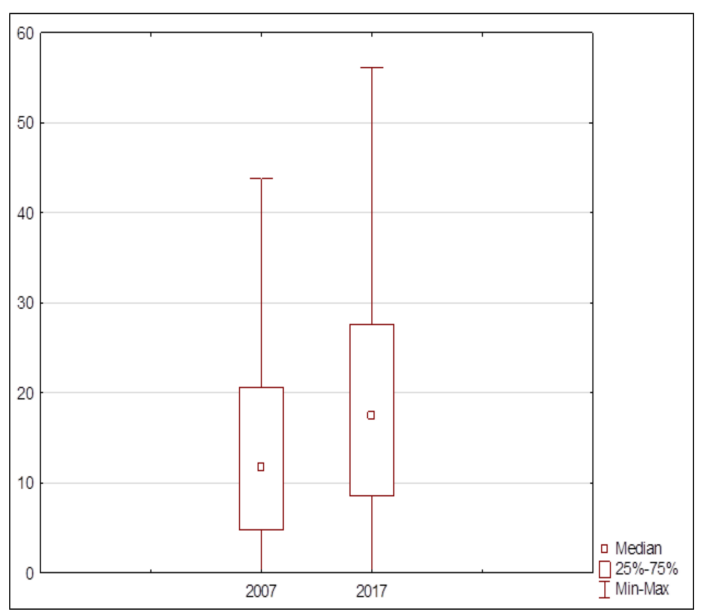

Figure 1. A box-plot for total liabilities per capita (in zlotys) and the share of total liabilities in total income (\%) in rural communes in Poland between 2007 and 2017. Source: the authors' compilation based on data published by the Ministry of Finance [32].

The comparison of individual groups of administrative units shows that rural communes were the least indebted group during the whole period under study. The median of the share of total liabilities in the total income of rural communes was 2-4 p.p. smaller than the median for the other administrative types. However, it is necessary to note the fact that this group of local government units was characterised by the greatest increase in the total debt. Simultaneously, this group was characterised by the greatest coefficient of variation and range in all the communes; it was equal to the maximum value of the debt indicators. It shows that this group of local government units was the most diversified in its indebtedness. During the whole period under study, there was high diversification, reaching the highest level between 2007 and 2009, i.e., nearly 70\%. Later it dropped to about 40\%. The increase in the median of the indicator under analysis and the increase in the coefficient of variation show that the group of rural communes facing the problem of growing indebtedness is becoming larger. It is noteworthy that regardless of the administrative type, in each group there were entities which exceeded the limit of the maximum share of the total debt in total income. However, among rural communes there were local governments with the biggest problems (Table 4).

There was a significant number of communes where the share of liabilities in the total income exceeded the limit of 50\%, which was assumed in this study. In 2017 , nearly $5 \%$ of rural communes exceeded this limit. It is noteworthy that it was the largest group among the administrative types under analysis. It is necessary to note that the number of communes which exceeded the limit of $50 \%$ for the indicator in question was the largest in 2011, when the total debt reached the highest level. It may have been caused by the fact that at the time many expensive investments were being financed with a share of EU funds. In 2007, there were only 20 communes in this group. In 2011, there were 252, whereas in 2017, there were 91 (Table 4). 
Table 4. The share of total liabilities in the total income of communes classified according to the administrative type in Poland between 2007 and 2017 (\%).

\begin{tabular}{|c|c|c|c|c|c|c|c|c|c|c|c|}
\hline \multirow{2}{*}{ Specification } & \multicolumn{11}{|c|}{ Share of Debt in Total Income (\%) } \\
\hline & 2007 & 2008 & 2009 & 2010 & 2011 & 2012 & 2013 & 2014 & 2015 & 2016 & 2017 \\
\hline \multicolumn{12}{|c|}{ Median } \\
\hline total & 14.3 & 13.3 & 18.0 & 28.6 & 32.7 & 31.6 & 29.7 & 29.4 & 25.6 & 20.3 & 19.3 \\
\hline urban & 18.9 & 17.5 & 26.6 & 32.5 & 35.4 & 35.8 & 33.9 & 31.7 & 29.2 & 22.7 & 21.4 \\
\hline urban-rural & 17.9 & 16.8 & 22.4 & 33.4 & 37.2 & 35.0 & 34.1 & 33.1 & 30.3 & 24.0 & 23.3 \\
\hline rural & 11.7 & 10.9 & 14.2 & 25.8 & 29.8 & 28.0 & 26.7 & 26.3 & 23.0 & 18.1 & 17.4 \\
\hline \multicolumn{12}{|c|}{ Range } \\
\hline total & 64.7 & 88.8 & 83.6 & 106.0 & 129.7 & 146.0 & 259.0 & 304.2 & 405.7 & 360.8 & 437.3 \\
\hline urban & 54.4 & 52.4 & 61.1 & 86.1 & 95.3 & 94.9 & 80.1 & 78.6 & 74.1 & 66.8 & 69.5 \\
\hline urban-rural & 64.0 & 62.1 & 78.5 & 83.1 & 129.7 & 99.6 & 106.4 & 93.9 & 129.2 & 89.1 & 275.9 \\
\hline rural & 64.7 & 88.8 & 83.6 & 106.0 & 110.7 & 146.0 & 259.0 & 304.2 & 405.7 & 360.8 & 437.3 \\
\hline \multicolumn{12}{|c|}{ Coefficient of variation * $(\%)$} \\
\hline total & 57.6 & 64.6 & 60.6 & 42.2 & 38.0 & 39.8 & 38.6 & 39.2 & 43.8 & 48.8 & 49.0 \\
\hline urban & 41.5 & 48.3 & 38.1 & 33.4 & 30.0 & 30.3 & 27.4 & 26.1 & 25.0 & 30.3 & 33.5 \\
\hline urban-rural & 45.2 & 53.5 & 48.2 & 34.1 & 28.4 & 32.0 & 32.1 & 33.5 & 35.5 & 39.9 & 41.8 \\
\hline rural & 66.5 & 74.6 & 72.7 & 47.5 & 41.8 & 44.6 & 44.0 & 43.7 & 48.1 & 53.9 & 54.7 \\
\hline \multicolumn{12}{|c|}{ Number of communes with share of liabilities in total income exceeding 50\% } \\
\hline total & 34 & 27 & 82 & 258 & 439 & 339 & 292 & 268 & 215 & 98 & 91 \\
\hline urban & 2 & 2 & 13 & 30 & 45 & 39 & 27 & 19 & 16 & 4 & 7 \\
\hline urban-rural & 12 & 9 & 31 & 79 & 142 & 122 & 111 & 102 & 82 & 36 & 31 \\
\hline rural & 20 & 16 & 38 & 149 & 252 & 178 & 154 & 147 & 117 & 58 & 53 \\
\hline
\end{tabular}

*: positional measure. Source: the authors' compilation based on data published by the Ministry of Finance [32]. 
There were similar statistics for the debt of urban and urban-rural communes. The debt indicator increased from $17-18 \%$ in 2007 to $35-37 \%$ in 2011, and then it dropped to $21-23 \%$ in 2017. In 2017, the most indebted urban communes were Świeradów-Zdrój (69.5\%), whereas the most indebted urban-rural communes were Byczyna (275.9\%), Lubsko (84.8\%) and Myślenice (77.4\%). In comparison with 2007, in 2017, the average debt of urban communes increased by $103.8 \%$, whereas the average debt of urban-rural communes increased by $145.1 \%$. It is necessary to add that the group of urban communes was more homogenous in terms of the indicator value, whereas urban-rural communes were more diversified. This fact is proved not only by the high coefficient of variation but also by high maximum values, which also indicate the range (Tables 3 and 4).

\subsection{Identifying the Financial Risk Factors of Excessive Indebtedness of Rural Communes by Means of Discriminant Analysis}

The first step in identifying the financial factors behind excessive indebtedness of rural communes based on the discriminative analysis was to pick the units at excessive debt levels, defined as those with a liabilities/total income ratio above 50\%. That group was by far the largest in 2012-2014, with 140 units (i.e., nearly $9 \%$ of all rural communes in Poland). Research suggests that excessive debt levels are found in rural communes of different functional types. However, typical units affected by excessive indebtedness are agricultural communes with a tourist function (nearly $17 \%$ of all communes of that type recoded excessive debt levels) and communes with residential and service functions (over 15\% of all communes of that type). Conversely, agricultural communes were less frequently affected by excessive indebtedness (only 6\% of them; the calculations are based on author's research presented in [2]). The key investment target for the authorities of tourist communes (located mainly in northern and southern Poland) was the enhancement of tourist and similar infrastructure. In turn, communes with residential and service functions (located in main metropolitan centers, in the immediate vicinity of big cities) mainly invested in the technical and social infrastructure. This was driven, on the one hand, by the needs of tourists, new residents or entrepreneurs and, on the other, by the capacity to meet these needs by accessing EU financing instruments. The purpose of investments implemented by communes (financed or co-financed with repayable funds) is to make the region more attractive (e.g., in terms of tourism or residential aspects). As a consequence, local government units derive more revenue from various types of local taxes (e.g., property tax, personal income tax) and local fees (e.g., visitors taxes, resort taxes). Usually, financial problems affecting these local government units resulted from the implementation of large-scale investments, sending them into a debt spiral. This is because the banks denied credit to them whereas shadow banks were eager to grant loans at an interest rate three times that charged by the banks [76].

Table 5 presents a selection of socioeconomic characteristics of rural communes at excessive debt levels and those with a debt maintained within one-half of their budgets. Heavily indebted communes demonstrate more favorable socioeconomic indicators than those which do not report excessive debt. Rural communes at high debt levels witnessed a higher positive net migration rate and a higher share of councilors with a higher level of education. Also, heavily indebted communes reported rapid growth of entrepreneurship as the number of operators entered to the REGON register per 10,000 population was much higher than in other rural communes. At the same time, residents of excessively indebted communes were more socially active as they establish foundations, associations and social organizations (Table 5). 
Table 5. Socioeconomic characteristics of excessively indebted Polish rural communes in 2012-2014 (average (median) values).

\begin{tabular}{|c|c|c|c|c|}
\hline \multirow[t]{2}{*}{ Specification } & \multicolumn{2}{|c|}{$\begin{array}{l}\text { Rural Communes in Which the Share of } \\
\text { Total Liabilities in Total Revenues }\end{array}$} & \multirow[t]{2}{*}{$t$} & \multirow[t]{2}{*}{$p$} \\
\hline & Was Less than $50 \%$ & Was Higher than $50 \%$ & & \\
\hline Share of arable land in total area (\%) & 66.92 & 58.92 & 5.06 & 0.00 \\
\hline $\begin{array}{l}\text { Population at non-working age per } 100 \text { persons } \\
\text { at working age }\end{array}$ & 59.96 & 58.99 & 2.20 & 0.03 \\
\hline Migration balance per 1000 people & 0.09 & 1.76 & -3.62 & 0.00 \\
\hline $\begin{array}{c}\text { Percentage of councilors with a high level of } \\
\text { education (\%) }\end{array}$ & 28.08 & 31.66 & -2.75 & 0.01 \\
\hline $\begin{array}{c}\text { Percentage of population using the sewage } \\
\text { system (\%) }\end{array}$ & 37.03 & 42.73 & -2.49 & 0.01 \\
\hline $\begin{array}{c}\text { Percentage of population using the gas } \\
\text { network }(\%)\end{array}$ & 15.56 & 20.95 & -2.41 & 0.02 \\
\hline Average floor area of the flat per person & 28.26 & 29.21 & -2.30 & 0.02 \\
\hline $\begin{array}{l}\text { Entities entered in the REGON register per } \\
10,000 \text { population }\end{array}$ & 687.76 & 800.16 & -4.93 & 0.00 \\
\hline $\begin{array}{l}\text { Newly registered units in the REGON register } \\
\text { per } 10,000 \text { population }\end{array}$ & 64.26 & 75.55 & -4.69 & 0.00 \\
\hline $\begin{array}{l}\text { Foundations, associations and social } \\
\text { organizations per } 10,000 \text { population }\end{array}$ & 32.38 & 34.76 & -2.38 & 0.02 \\
\hline
\end{tabular}

The discriminant model of the risk of excessive indebtedness of rural communes was built in four stages. At the first stage, the aim of the study and classification criteria were defined, and a group of local government units was selected for analysis. The aim of the study was to build a discriminant model enabling prediction of the danger of excessive indebtedness of rural communes and identification of the financial factors of excessive indebtedness of these entities. The model includes ten financial indicators selected based on substantive and statistical criteria (Step 2).

The first step of the research method consisted of entering the share of the operating surplus in total income $(O S / T I)$ as a variable. It was characterised by the greatest discriminatory power due to the greatest $F$ statistic value (Table 6). Further steps involved entering the share of own income in total income $(O I / T I)$ and the amount of the EU funds in zlotys per capita $(E U / M)$ as variables. The third step was the final one, because the other variables did not have sufficient discriminatory power due to the low $F$ statistic value. Table 7 shows the data characterising the variables in the model. The critical significance level $p$ shows that the variables significantly contributed to distinguishing between rural communes threatened or unthreatened by excessive indebtedness. The value of partial Wilks' lambda indicates that the OS/TI variable had the greatest discriminatory contribution.

Table 6. The results of an analysis of the discriminant function (stepwise progressive method).

\begin{tabular}{ccccc}
\hline Step & $\begin{array}{c}\text { Number of } \\
\text { Variables }\end{array}$ & $\begin{array}{c}\text { Last Variable } \\
\text { Entered }\end{array}$ & Wilks' Lambda & F \\
\hline Step 1 & 1 & OS/TI & 0.9742 & 13.87 \\
Step 2 & 2 & OI/TI & 0.9118 & 3.51 \\
Step 3 (final step) & 3 & EU/M & 0.9028 & 2.01 \\
\hline
\end{tabular}

Source: the authors' calculations based on data published by the Ministry of Finance [32] and Central Statistical Office [1]. 
Table 7. A summary of analysis of the discriminant function.

\begin{tabular}{cccc}
\hline Variable & Partial Wilks' Lambda & Toleration & $p$ \\
\hline OS/TI & 0.9143 & 0.9515 & 0.0003 \\
OI/TI & 0.9769 & 0.9157 & 0.2310 \\
EU/M & 0.9866 & 0.9451 & 0.0358 \\
\hline
\end{tabular}

Source: as in Table 2.

Canonical analysis was conducted in order to obtain the discriminant function coefficients. It resulted in raw and standardised coefficients. Raw coefficients are better suited for classification. The estimated discriminant function with raw coefficients had the following form:

$$
Z=0.6524+5.5928 \text { OS/TI }-0.5843 \text { OI/TI-0.6187 EU/M }
$$

In an interpretation of the parameter values in the estimated model, we can say that the smaller the share of the operating surplus in total income is as well as the greater the share of own income in total income and the amount of the EU funds in zlotys per capita are, the lower the discriminatory value of the function and the higher the risk of excessive indebtedness of a local government unit. The study revealed that the risk of excessive indebtedness is most likely to occur in the rural communes that are more financially independent and those that make intensive investments in socioeconomic development by acquiring EU funds for this purpose.

According to the rule of co-financing, the EU funds are supposed to supplement local government entities' own funds, but they should not replace them. It is required that the commune should make its own contribution. Additionally, it is necessary to stress the fact that the funds received from the EU for a project must be repaid. This solution may also influence the commune's financial liquidity [77]. Due to the fact that local government entities' own income is limited, especially in rural communes, it is increasingly often replaced by repayable instruments received by a local government unit. It is necessary to remember that although it is possible to finance investments with repayable funds, the resulting excessive indebtedness causes future instability of public finance. Local authorities should assess the efficiency of investment expenditure because large amounts of liabilities to be paid by future generations may inhibit the socioeconomic development of these entities not only on a local but also national scale. Note that the procedure for calculating the debt ratio of local government entities had changed in recent years. The debt related to the implementation of EU projects is not taken into account when calculating the debt ratio [32]. The objective of this amendment was to help the communes finance their own contribution with debt instruments. Therefore, it drove interest in, and expanded the use of, repayable instruments.

The share of the operating surplus in total income proved to be an important financial risk factor of excessive indebtedness of rural communes. The lower the ratio is, the higher the risk of excessive indebtedness of a particular commune. An operating surplus indicates investment capacity, and it is the source from which a local government unit can pay its liabilities. Since 2014, it has been the parameter determining the indebtedness threshold according to the algorithm [46]. According to Dylewski [78], relatively low capacity to generate an operating surplus may be a financial risk factor causing excessive indebtedness not only in rural communes but also in other entities of the local government sector. It may also be a barrier blocking the possibility to finance, pre-finance or participate in financing new investments in the financial perspective of 2014 to 2020. Since 2014, there have been new legal regulations concerning the maximum debt of local government units. Individual creditworthiness is determined for each local government unit. It is an individual debt indicator calculated from the mean operating surplus in the last or three or seven years (the changes take effect gradually).

Having determined the discriminant function, the fourth stage consisted of specifying the limit according to which a particular local government unit could be classified into the group of rural communes threatened by the risk of excessive debt or into the group of unthreatened communes. The limit value 
between the groups is 0 because the discriminant function is estimated by means of a sample with the same number of communes in both groups (cf. [79]). The population of rural communes is classified according to the values of the discriminant function $(Z)$. Table 8 shows the results of the classification of the communes under study, where $Z_{\text {limit }}=0$. According to Wisniewski, [43] stresses the fact that the accuracy of classification is the most measurable empirical evaluation of the quality of the estimation model. The classification matrix shows that the overall accuracy of classification was relatively high and amounted to more than $60 \%$. In investigations of the risk of bankruptcy of different entities, the so-called grey zone is also determined. It is an interval of values with both positive and negative results (cf. [37]).

Table 8. The accuracy of classification of rural communes in Poland according to the estimated discriminant function $\left(Z_{\text {limit }}=0\right)$.

\begin{tabular}{cccc}
\hline \multirow{2}{*}{ Actual Grouping of Communes } & $\begin{array}{c}\text { Classification } \\
\text { Correctness (\%) }\end{array}$ & \multicolumn{2}{c}{ Communes Classified According to Model } \\
\cline { 3 - 4 } & 62.1 & Class 1 & Class 2 \\
\hline Class 1-communes threatened by & & 87 & 53 \\
$\quad \begin{array}{c}\text { excessive indebtedness } \\
\text { Class 2-communes unthreatened } \\
\text { by excessive indebtedness }\end{array}$ & 62.1 & 53 & 87 \\
Total & 62.1 & 140 & 140 \\
\hline
\end{tabular}

Source: as in Table 2.

Rural communes were categorised into one of three groups, according to the following limits: I $(Z<-0.5)$-rural communes with high risk of excessive indebtedness, II ( $-0.5 \leq Z \leq 0.5)$-grey zone (rural communes requiring in-depth analysis), III ( $Z>0.5)$ - rural communes unthreatened by excessive indebtedness (Table 9). The discriminant model based on these limits had a high prognostic accuracy of near $70.0 \%$. The rural communes with the grey zone value of function $\mathrm{Z}$ cannot be allocated either to the group of local government entities threatened by excessive indebtedness or the group of unthreatened entities. Their financial situation needs to be given in-depth analysis.

Table 9. The accuracy of classification of rural communes in Poland according to the estimated discriminant function (class 1 : $Z<0.5$, class 2 : $Z>0.5$, grey zone: $-0.5 \leq Z \leq 0.5$ ).

\begin{tabular}{ccccc}
\hline \multirow{2}{*}{ Actual Grouping of Communes } & $\begin{array}{c}\text { Classification } \\
\text { Correctness (\%) }\end{array}$ & \multicolumn{2}{c}{ Communes Classified According to Model } \\
\cline { 3 - 5 } & 69.7 & 53 & Class 2 & Grey Zone \\
\hline $\begin{array}{c}\text { Class 1-communes threatened by } \\
\begin{array}{c}\text { excessive indebtedness } \\
\text { Class 2-communes unthreatened }\end{array}\end{array}$ & 69.0 & 27 & 23 & 64 \\
by excessive indebtedness & 69.3 & 80 & 60 & 53 \\
Total & & & 83 & 117 \\
\hline
\end{tabular}

Source: as in Table 2.

The discriminative model of excessive indebtedness of rural communes in 2012-2014 was compared to models built based on 2007-2008 and 2015-2017 data (Table 10). The analysis of discriminative models developed in this study suggests that the main factors of risk of excessive indebtedness facing rural communes in 2007-2009 were the self-financing capacity, own potential income, and access to European Union funds. The analysis of signs of the model's parameters shows that the higher the self-financing indicator, and the lower the share of own income in total income, and the lower the share of own incomes in total incomes, and the lower the share of EU funds accessed per capita, the smaller are the values of function $Z$ and, thus, the greater is the risk of excessive indebtedness facing the communes. Therefore, in 2007-2009 (i.e., at the beginning of the financial perspective of 2007 to 2013), debt was mainly incurred by communes at lower levels of own income potential which until that time did not access EU funds. However, the model needs to be interpreted with caution because of the 
poor representativeness of the sample (as only 15 rural communes experienced excessive indebtedness in the study period). In turn, in 2015-2017, the financial factors of risk of excessive debt facing the rural communes were similar to those identified in 2012-2014, a period where excessive indebtedness of communes became most widespread. The analysis of the signs of the model's parameters shows that the higher the own income potential (the higher the share of own incomes in total incomes), and the lower the share of the operating surplus in total incomes, the higher are the values of function $\mathrm{Z}$ and, thus, the greater is the risk of excessive indebtedness facing the communes. Hence, in recent years, excessive indebtedness was a risk faced mainly by communes at higher levels of own income potential, mostly including those, which in addition to their agricultural function, also had residential, service and tourist functions. In order to improve their competitive edge over other communes, they willingly invested in local development by accessing repayable sources of financing.

Table 10. Estimated discriminatory functions of risk of excessive indebtedness of Polish rural communes.

\begin{tabular}{|c|c|c|c|}
\hline \multirow{2}{*}{ Specification } & \multicolumn{3}{|c|}{ Years } \\
\hline & 2007-2009 & 2012-2014 & 2015-2017 \\
\hline $\begin{array}{c}\text { Form of estimated } \\
\text { discriminant function }(Z)\end{array}$ & $\begin{array}{c}Z=-0.8463 \text { SFR }+0.5753 \\
O I / T I+0.5177 E U / M\end{array}$ & $\begin{array}{c}Z=0.6524+5.5928 \\
\text { OS/TI-0.5843 OI/TI-0.6187 } \\
E U / M\end{array}$ & $\begin{array}{c}Z=-1.3031 \text { OI/TI }+1.2272 \\
\text { OS/TI }\end{array}$ \\
\hline $\begin{array}{l}\text { Correctness of } \\
\text { classification }(\%)\end{array}$ & $80.0 \%$ & $61.8 \%$ & $68.8 \%$ \\
\hline $\begin{array}{l}\text { Size of sample of } \\
\text { excessively indebted } \\
\text { communes }\end{array}$ & 15 & 140 & 61 \\
\hline
\end{tabular}

Source: as in Table 2.

\subsection{Discussion}

As shown by the analysis of excessive indebtedness or, generally, of the fiscal health of public entities, there are multiple assessment methods and groups of indicators used in measuring these developments. This results in considerable disagreements $[26,80,81]$. In the US alone, several states have developed their own systems for measuring the fiscal condition of their local governments [82]. An indicator-based analysis is among the proposed measurement methods [83]. Note however that the selection of indicators is problematic. For instance, Finkler, Smith, Calabrese and Purtell [84] recommend 19 different indicators while others rely on 29 indicators [85]. One of the most widely used measurement systems is Brown's 10-point test [86]. The test consists of 14 indicators, many of which were also used in the assessment procedure in this paper (with respect to expenditure and income, including tax income). According to Maher and Nollenberger [80], they are relatively simple to use. In turn, Wang, Dennis and Tu [26] relied on the solvency test with 11 indicators relating to cash, budget, long-run, and service. Note that they consider the calculation of surpluses/deficits, which were also used in this paper.

It needs to be emphasized that the discriminatory analysis can be used in forecasting a disadvantageous financial situation. Rarely used with respect to public entities, it mostly serves to forecast business failures. In Poland, E. Mączyńska [45] was the first one to develop a linear model of a discriminatory function of the risk of business failure. Research was also carried out by D. Hadasik, A. Hołda, M. Hamrol and many other scientists $[87,88]$.

Considering the variables of the discriminatory model, the studies corroborate the findings by other authors. Some researchers, including Filipiak [89], believe the insufficient amount of non-repayable financing and the restricted financial autonomy of communes to be among the reasons behind local government debt. As noted by Dafflon and Beer-Toth [90], debt is one of the natural ways to fulfill a unit's tasks. It provides an alternative way of financing, especially if the LGU does not have enough own funds, and evidences its efficiency in using all available sources of financing. The importance of financial autonomy for the risk of excessive indebtedness is also indicated in research by Kata [91]. He 
believes that a dangerous situation occurs if municipal finance is threatened by several risks, e.g., high indebtedness accompanied by low levels of financial autonomy. Standar and Kozera [52] used such a discriminatory model in examining one of the Polish regions. Their findings were very much the same. The regional model covered four variables and the share of investment expenditure per capita. This formed a basis for drawing conclusions on whether that method is useful in this kind of studies.

\subsection{Political Implications}

Both the European Union and national legislation imposes restrictions on public debt, including in the public finance sector. When it comes to European Union law, the Treaty on the Functioning of the European Union [92] stipulates that the stock of government debt, in addition to deficit restrictions, is the criterion used by the Commission to examine compliance with budgetary discipline in member states (Article 126), and defines what is referred to as the Excessive Deficit Procedure (EDP). The Protocol on the Excessive Deficit Procedure [93], as enclosed to the Treaty on European Union and the Treaty on the Functioning of the European Union [92], defines debt and sets the baseline for the public debt/GDP ratio at 60\%. Council Regulation (EC) No. 479/2009 of 25 May 2009 [94] specifies the titles of public debt. In turn, Regulation (EU) No. 549/2013 [95] of the European Parliament and of the Council of 21 May 212013 on the European system of national and regional accounts in the European Union (ESA 2010) defines the categories of financial liabilities and the general government sector. In the Polish legislation, the following legal acts are of key importance in that respect: Constitution of the Republic of Poland, and Public Finance Act [96].

The growing debt of the Polish public sector, including at the commune level, resulted in amendments to legal regulations. First of all, a new solution was introduced for calculating the debt limits. The objective was to customize the safe debt indicator and make it dependent upon financial standing (the previous algorithm failed to do so). Also, some other issues were regulated, including the implementation of resolution measures for local government units at risk of jeopardizing their public tasks. Steps taken in such circumstances include restricting new investments so as not to generate more debt and restricting the expenditure on compensation of the management and councilors. At the same time, with a more stringent debt limit, in order to increase the local government units' capacity to absorb European Union funds, the restrictions provided for in the Public Finance Act were eased. The debt ceiling does not apply to some items any longer, including interest on debt incurred to implement projects co-financed by the European Union, and the debt incurred to co-finance the expenses under an EU program, project or task which is more than $60 \%$ subsidized by the EU [75]. Also, since 2011, local governments have been required to establish multiannual financial forecasts. This is how the scope of published forecasts of debt levels and servicing costs was extended. It is an important aspect of local budget planning. The significance of changes in that respect is reflected by the fact that in recent years, commune offices have established separate organizational units to deal with debt issues. According to many experts in this field, e.g., Hałaburda [97], these changes consist of handing the responsibility for the growing public debt over to local government units. These solutions give rise to doubts, especially in a situation where the government focuses its policy on extending the scope of LGUs' tasks without enhancing their income base.

Currently, the objective of Polish regulations is to rationalise the local government's ability to incur debt, make their financial management more flexible and strengthen the legal mechanisms designed to improve financial security. The key draft amendments are to enable restructuring the debt of LGUs through the repayment of existing debt with new debt at lower servicing costs, or through early repayment if own funds are available. The above also strengthens the legal mechanisms designed to improve the financial security of LGUs, for instance, by calculating the individual debt repayment indicator so as to take account of liabilities whose economic effects are similar to those of a loan or credit agreement (including customised financial instruments); this will allow elimination of the circumvention of the debt indicator and, thus, will improve financial security at LGU level (2019-2022 Debt Management Strategy for the Public Finance Sector, 2018) [96]. 


\section{Conclusions}

Repayable financing allows local government units to function when their income does not correspond to the costs of tasks implemented. It also enables these entities to maintain high investment expenditures when their investment potential is low. However, it is necessary to face the problem of safe indebtedness of local government units and to manage the debt appropriately. Excessive indebtedness of entities in the local government sector causes dangers. During an economic downturn, the financial condition is worse and it is a specific barometer indicating local development perspectives. Excessive indebtedness of local government units is a danger not only to their stability and to local development, but also to the entire public finance sector.

The problem of increasing indebtedness can be observed in a growing number of communes and on an increasing scale in Poland. Between 2007 and 2017, rural communes were the least indebted group. However, the greatest increase in the total amount of debt was observed in this group. Apart from that, due to the diversified functions of rural communes, this group was characterised by the greatest diversification both in the amount of debt and the share of total debt in the communes' budgets. Apart from that, in this group, there were entities facing the biggest problems caused by excessive indebtedness. However, typical units affected by excessive indebtedness are agricultural communes with a tourist function and communes with residential and service functions. In turn, agricultural communes are affected less frequently. The key investment target for the authorities of tourist communes (located mainly in northern and southern Poland) was the enhancement of tourist and similar infrastructure. In turn, communes with residential and service functions (located in main metropolitan centers, in the immediate vicinity of big cities) mainly invested in technical and social infrastructure.

There is a large number of factors of the total debt of communes and the debt of rural communes in Poland. Financial factors are one of the causes of indebtedness. The discriminant analysis showed that in 2012-2014, the share of the operating surplus and own income in total income as well as the amount of EU funds per capita in zlotys) were particularly significant. The study revealed that the smaller the share of the operating surplus in total income is as well as the greater the share of own income in total income and the amount of the EU funds in zlotys per capita are, the lower the value of the estimated discriminatory function and the higher the risk of excessive indebtedness of a rural commune. Thus, we can conclude that the risk of excessive indebtedness is most likely to occur in the rural communes that are more financially independent (characterised by a higher level of own income potential) and in those that make intensive investments in socioeconomic development by acquiring the EU funds for this purpose. The discriminative model of excessive indebtedness of rural communes in 2012-2014 was compared to models built based on 2007-2008 and 2015-2017 data. In 2007-2009 (i.e., at the beginning of the financial perspective of 2007-2013), debt was mainly incurred by communes at lower levels of own income potential which until that time did not access EU funds. In turn, in 2015-2017, the financial factors of risk of excessive indebtedness facing the rural communes were similar to those identified in 2012-2014.

This study allowed us to confirm the research hypothesis that the main determinant of the risk of excessive indebtedness is the rural communes' own income potential. Considerable indebtedness of many rural communes in Poland, low investment capacity and relatively low operating surplus generated by these entities of the local government sector may become barriers blocking their local development. In the current financial perspective, the human factor in the entities of the local government sector seems to be a particularly important element conditioning appropriate debt management and local development of rural communes. In view of the fact that rural communes' own funds are limited and these entities have poor capacity to incur new liabilities due to the low operating surplus generated, in the financial perspective of 2014-2020, it will be particularly important to consider all investment plans carefully in terms of the costs borne and potential long-term benefits.

Author Contributions: Conceptualization, A.S., A.K.; data curation, A.S., A.K.; formal analysis, A.K.; methodology, A.K., A.S.; project administration, A.S.; resources, A.K., A.S.; software, A.K., A.S.; visualization, A.K., A.S; writing-original draft preparation, A.S., A.K.; writing-review and editing, A.K., A.S.; funding acquisition, 
A.S., A.K; investigation, A.K., A.S.; supervision, A.S.; validation, A.K. All authors have read and agreed to the published version of the manuscript.

Funding: The research was co-financed from resources of the National Center for Science, allocated pursuant to decision DEC-2013/11/D/HS4/03884 and the Faculty of Economics and Social Sciences Poznań University of Life Sciences.

Conflicts of Interest: The authors declare no conflict of interest.

\section{References}

1. Central Statistical Office. Local Data Bank Database. Available online: http://www.stat.gov.pl/bdl (accessed on 16 January 2019). (In Polish)

2. Kozera, A.; Głowicka-Wołoszyn, R. Identification of functional types of rural communes in Poland. In Proceedings of the 2018 International Scientific Conference Economic Sciences for Agribusiness and Rural Economy, Economic Sciences for Agribusiness and Rural Economy, Warsaw, Poland, 7-8 June 2018; Volume 1, pp. 109-115.

3. Kozera, A. Własny potencjał dochodowy gmin wiejskich w Polsce (Own income potential of rural communes in Poland). Polityki Eur. Finans. I Mark. 2018, 19, 95-106. (In Polish)

4. Kata, R. Ryzyko finansowe w kontekście zadłużenia jednostek samorządu terytorialnego w Polsce (Financial risk in the context of indebtedness of local government units in Poland). Optim. Studia Ekon. 2015, 4, 54-71. Available online: http://sj.wne.sggw.pl/pdf/EIOGZ_2012_n96_s129.pdf (accessed on 16 January 2019). (In Polish). [CrossRef]

5. Carmeli, A. The Effect of Fiscal Conditions of Local Government Authorities on Their Economic Development. Econ. Dev. Q. 2007, 21, 91-98. [CrossRef]

6. Watson, D.J.; Handley, D.M.; Hassett, W.L. Financial distress and municipal bankruptcy: The case of Prichard, Alabama. J. Public Budg. Account. Financ. Manag. 2005, 17, 129-150. [CrossRef]

7. Carmeli, A. The fiscal distress of local government in Israel. Adm. Soc. 2008, 39, 984-1007. [CrossRef]

8. Pagano, M.; Moore, R.J.T. Cities and Fiscal Choices: A New Model of Urban Public Investment; Duke University Press: Durham, NC, USA, 1985.

9. Rabiczko, A.; Puszko, K. Czy polskim jednostkom samorzadu terytorialnego grozi widmo spirali zadłużenia? (Is the specter of a spiral of debt threatening Polish local self-government units?). In Finanse samorzadu Terytorialnego W Niestabilnym Otoczeniu (Local Government Finances in an Unstable Environment); Poniatowicz, M., Ed.; Wydawnictwo Uniwersytetu w Białymstoku: Białystok, Poland, 2013; pp. 77-84.

10. Brzozowska, K.; Gorzałczyńska-Koczkodaj, M.; Kogut-Jaworska, M.; Zioło, M. Gospodarka Finansowa W Jednostkach Samorzadu Terytorialnego (Financial Economy in Local Government Units); CeCeWu: Warszawa, Poland, 2013. (In Polish)

11. Fisher, R.C. State and Local Public Finance; Foresman and Company: Glenview, IL, USA, 1987.

12. Alesina, A.; de Broeck, M.; Prati, A.; Tabellini, G. Default Risk on Government Dept in OECD Countries in: Economic Policy. Eur. Forum 1992, 7, 428-463.

13. Gianakis, G.A.; McCue, C.P. Local Government Budgeting; Praeger: Westport, CT, USA, 1999.

14. Dafflon, B. Local Debt: From Budget Responsibility to Fiscal Discipline; Université de Fribourg: Fribourg, France, 2010.

15. Burret, H.T.; Feld, L.P. A note on budget rules and fiscal federalism. CESifo DICE Rep. 2014, 12, 3-11.

16. Poniatowicz, M. Dtug Publiczny W Systemie Finansowym Jednostek Samorzadu Terytorialnego (Public Debt in the Financial System of Local Government Units on the Example of Cities with Poviat Rights); Wydawnictwo Uniwersytetu w Białymstoku: Białystok, Poland, 2005.

17. Kosak-Wojnar, M.; Surówka, K. Podstawy Finansów Samorządu Terytorialnego (Basics of Local Government Finances); Wydawnictwo PWN: Warszawa, Poland, 2007. (In Polish)

18. Filipiak, B. Przesłanki dokonania oceny samorzadowego długu publicznego na tle podejścia badawczego (Estimating the level of indebtedness of local government units in conditions of an increased risk of losing financial liquidity). In Szacowanie Poziomu Zadłużenia Jednostek Samorzadu Terytorialnego W Warunkach Zwiększonego Ryzyka Utraty Płynności Finansowej (The Rationale for Assessing Local Government Debt Against the Background of the Research Approach); Denek, E., Dylewski, M., Eds.; Difin: Warszawa, Poland, 2013; pp. 169-208. (In Polish) 
19. Standar, A. The problem of indebtedness of Polish communes. Hradec Econ. Days 2017, 7, 821-828.

20. Wood, L.E. Trends in National and Regional Economic Distress: 1960-2000, Prepared for the Appalachian Regional Commission. Available online: https://www.arc.gov/research/researchreportdetails.asp?REPORT_ ID $=28$ (accessed on 20 May 2019).

21. Honadle, B.W.; Costa, J.M.; Cigler, B.A. Fiscal Health for Local Governments; Elsevier: London, UK, 2003.

22. Trussel, J.M.; Patrick, P.A. The Symptoms and Consequences of Fiscal Distress in Municipalities: An Investigation of Reductions in Public Services. Account. Public Interest 2013, 13, 151-171. [CrossRef]

23. Kloha, P.; Weissert, C.; Kleine, R. Someone to Watch Over Me: State Monitoring of Local Fiscal Conditions. Am. Rev. Public Adm. 2005, 35, 236-255. [CrossRef]

24. Jones, S.; Walker, R. Explanators of Local Government Distress. Abacus 2007, 63, 396-418. [CrossRef]

25. Hendrick, R. Assessing and Measuring the Fiscal Health of Local Government: Focus on Chicago Suburban Municipalities. Urban Aff. Rev. 2004, 40, 78-114. [CrossRef]

26. Wang, X.; Dennis, L.; Tu, Y.S.J. Measuring financial condition: A study of US states. Public Budg. Financ. 2007, 27, 1-21. [CrossRef]

27. Rivenbark, W.C.; Roenigk, D.J. Implementation of Financial Condition Analysis in Local Government. Public Adm. Q. 2011, 35, 241-267. [CrossRef]

28. Ambrose, B.W.; Deng, Y.; Wu, J. Understanding the Risk of China's Local Government Debts and its Linkage with Property Markets. Presented at the International Symposium on Housing and Financial Stability in China, Shenzhen, China, 18-19 December 2015; pp. 1-43. [CrossRef]

29. Aczél, Á.; Homolya, D. Risks of the indebtedness of the Hungarian local government sector from a financial stability point of via. In Crisis Aftermath: Economic Policy Changes in the EU and Its Member States Conference Proceedings; Munich Personal RePEc Archive Paper 40345; University Library of Munich: Munich, Germany, 2012; pp. 157-169. Available online: http://mpra.ub.uni-muenchen.de/40345 (accessed on 19 September 2019).

30. Bolívar, M.P.R.; Galera, A.N.; Muñoz, L.A.; Subirés, M.D.L. Risk Factors and Drivers of Financial Sustainability in Local Government, An Empirical Study. Local Gov. Study 2016, 42, 29-51. [CrossRef]

31. Standar, A. Zagrożenia w gospodarce finansowej samorządów gminnych a wyrównywanie poziomu rozwoju lokalnego (Threats in the financial economy of gmina local governments and equalization of the level of local development). Nierówności Społeczne Wzrost Gospod. 2017, 49, 359-371. (In Polish) [CrossRef]

32. Wskaźniki do Oceny Sytuacji Finansowej Jednostki Samorzadu Terytorialnego (Indicators for Assessment of the Financial Situation of Local Government Units); Ministry of Finance: Warsaw, Poland, 2016. Available online: http: //www.finanse.mf.gov.pl/budzet-panstwa/finanse-samorzadow/opracowania (accessed on 16 January 2019). (In Polish)

33. Archiwalne Średnie Kursy (Archive of Medium Courses); Narodowy Bank Polski: Warsaw, Poland, 2018.

34. Tukey, J.W. Exploratory Data Analysis; Addison-Wesley: Boston, MA, USA, 1977.

35. Wysocki, F. Metody Taksonomiczne W Rozpoznawaniu Typów Ekonomicznych Rolnictwa I Obszarów Wiejskich (Taxonomic Methods in Recognizing Economic Types of Agriculture and Rural Areas); Wydawnictwo Uniwersytetu Przyrodniczego w Poznaniu: Poznań, Poland, 2010.

36. Reimann, C.; Filzmoser, P.; Garrett, R.; Dutter, R. Statistical Data Analysis Explained-Applied Environmental Statistics with R; John Wiley \& Sons Ltd.: Chichester, West Sussex, UK, 2008.

37. Wysocki, F.; Kozera, A. Wykorzystanie analizy dyskryminacyjnej w ocenie ryzyka upadłości przedsiębiorstw przemysłu mięsnego (The use of discriminant analysis in assessing the risk of bankruptcy of food industry enterprises). J. Agribus. Rural. Dev. 2012, 4, 167-182. (In Polish)

38. Zielińska-Chmielewska, A. Use of chosen discrimınatıon models in the assessment of bankruptcy risk in meat processing enterprises. J. Agribus. Rural. Dev. 2015, 36, 363-370. [CrossRef]

39. Tabachnick, B.G.; Fidell, L. Using Multivariate Statistics, 3rd ed.; Happer\&Row: New York, NY, USA, 1996.

40. Stanisz, A. Przystępny kurs statystyki z zastosowaniem STATISTICA PL na przykładach z medycyny. In Tom 3. (An Affordable Statistic Course Using STATISTICA PL on Examples of Medicine. Volume 3); Statsoft: Kraków, Poland, 2007.

41. Johnson, R.A.; Wichern, D.W. Applied Multivariate Statistical Analysis, 5th ed.; Prentice Hall: Upper Saddle River, NJ, USA, 2002.

42. Altman, E.I. Financial ratios, discriminant analysis and the prediction of corporate bankruptcy. J. Financ. 1968, 23, 589-609. [CrossRef] 
43. Wiśniewski, M. Ocena Zdolności Kredytowej Gminy (Credit Rating of a Commune); Difin: Warszawa, Poland, 2011.

44. Huberty, C.J. Applied Discriminant Analysis; John Wiley Sons Inc.: New York, NY, USA, 1994.

45. Mączyńska, E.; Zawadzki, M. Dyskryminacyjne modele predykcji bankructwa przedsiębiorstw (Discriminating bankruption prediction models for enterprises). Ekonomista 2006, 2, 1-24.

46. Afifi, A.; May, S.; Clark, V.A. Practical Multivariate Analysis; CRC Press/Taylor: Florida, FL, USA, 2012.

47. Public Finance Act of June 30, 2005. Journal of Laws of 2005, No. 249, Item 2104. Available online: http://prawo.sejm.gov.pl/isap.nsf/download.xsp/WDU20052492104/U/D20052104Lj.pdf (accessed on 18 April 2019).

48. Dylewski, M. Analiza pionowa i pozioma sprawozdań jednostki samorządu terytorialnego (Vertical and horizontal analysis of the reports of local government units). In Metody Analityczne W Działalności Jednostek Podsektora Samorzadowego (Analytical Methods in the Activity of Local Government Units); Dylewski, M., Filipiak, B., Gorzałczyńska-Koczkodaj, M., Eds.; Difin: Warszawa, Poland, 2010; pp. 76-91. (In Polish)

49. Bański, J. Perspektywy rozwoju polskiej wsi-wybrane zagadnienia (Prospects for the development of the rural areas of Poland-Selected issues). Wieś I Rol. 2014, 4, 13-25. Available online: http://kwartalnik. irwirpan.waw.pl/archive?year=2014 (accessed on 18 April 2019). (In Polish).

50. Hadyński, J. Regionalna Konkurencyjność Obszarów Wiejskich (Regional Competitiveness of Rural Areas); Wydawnictwo Uniwersytetu Przyrodniczego w Poznaniu: Poznań, Poland, 2015. (In Polish)

51. Heffner, K.; Klemens, B. Obszary Wiejskie: Wiejska Przestrzeń I Ludność, Aktywność Społeczna I Przedsiębiorczość (Rural Areas: Rural Space and Population, Social Activity and Entrepreneurship). Polska Akademia Nauk; Heffner, K., Klemens, B., Eds.; Komitet Przestrzennego Zagospodarowania Kraju: Warszawa, Poland, 2016.

52. Standar, A.; Kozera, A. Wykorzystanie analizy dyskryminacyjnej w ocenie ryzyka nadmiernego zadłużenia jednostek samorządu terytorialnego na przykładzie gmin województwa wielkopolskiego (The use of discriminant analysis in the evaluation of risk of excessive debt of local government units for example communes of Wielkopolska province). Finans. Rynk. Finans. Ubezpieczenia 2016, 4, 805-818. (In Polish) [CrossRef]

53. Kozera, A. Problem zadłużenia gmin wiejskich na przykładzie województwa wielkopolskiego (The problem of indebtedness in rural gminas based on the example of Wielkopolskie province). Wieś I Rol. 2017, 1, 75-97. (In Polish) [CrossRef]

54. Kozera, A. Rosnące zadłużenie jednostek samorząu terytorialnego jako zagrożenie dla rozwoju lokalnego (The growing debt of local government units as a threat to local development). Nierówności Społeczne Wzrost Gospod. 2017, 49, 203-2014. (In Polish) [CrossRef]

55. Standar, A. Identyfikacja poziomu ryzyka w zakresie nadmiernego zadłużenia sie gmin i jego finansowych determinant (Identyfication of the level of risk in terms of municipal excessive indebtedness and its financial determinants). Nierówności Społeczne Wzrost Gospod. 2018, 56, 121-132. (In Polish) [CrossRef]

56. Rosner, A.; Stanny, M. Socio-Economic Development of Rural Areas in Poland, The European Fund for the Development of Polish Villages Foundation, Institute of Rural and Agricultural Development; Polish Academy of Sciences: Warsaw, Poland, 2017.

57. Wilkin, J.; Nurzyńska, I. (Eds.) Rural Poland 2018-The Report on the State of Rural Areas; Scholar Publishing House: Warszawa, Poland, 2018.

58. Constitution of the Republic of Poland of 2 April 1997. Journal of Laws of 1997, No. 78, Item 483. Available online: http://prawo.sejm.gov.pl/isap.nsf/download.xsp/WDU19970780483/U/D19970483Lj.pdf (accessed on 16 January 2019). (In Polish)

59. Public Finance Act of August 27, 2009, Journal of Laws of 2009, No. 157, Item 1240. Available online: http:// prawo.sejm.gov.pl/isap.nsf/download.xsp/WDU20091571240/U/D20091240Lj.pdf (accessed on 18 April 2019).

60. Act on Local Government Revenues, Article 3, Journal of Laws of 2003, No. 203, item 1966 (Ustawa O Dochodach Jednostek Samorządu Terytorialnego). Available online: http://prawo.sejm.gov.pl/isap.nsf/ download.xsp/WDU20032031966/U/D20031966Lj.pdf (accessed on 18 November 2019). (In Polish)

61. Act of 8 March 1990 on communal self-government, Journal of Laws of 1990, No. 16, item 95 (Ustawa O Samorządzie Gminnym). Available online: http://prawo.sejm.gov.pl/isap.nsf/download.xsp/ WDU19900160095/U/D19900095Lj.pdf (accessed on 18 November 2019). (In Polish)

62. European Charter of Local Self-Government; European Treaty Series No. 122; Council of Europe: Strasbourg, France, 1985. 
63. Jastrzębska, M. Finanse Jednostek Samorzadu Terytorialnego (Finances of Local Government Units); LEX a Wolters Kluwer Business: Warszawa, Poland, 2012. (In Polish)

64. Šević, Z. Fiscal Decentralisation and Grant Transfers in Transition Countries: A Critical Perspective; Šević, Z., Ed.; The Network of Institutes and Schools of Public Administration in Central and Eastern Europe: Bratislava, Slovakia, 2005.

65. Rusu, E. Comparative analysis of local financial autonomy in the European Union countries. Ann. Ştefan Cel Mare Univ. Suceava 2008, 8, 224-230.

66. Surówka, K. Samodzielność Finansowa Samorzadu Terytorialnego W Polsce (Financial Independence of Local Government in Poland); Polskie Wydawnictwo Ekonomiczne: Warszawa, Poland, 2013. (In Polish)

67. Satola, Ł.; Standar, A.; Kozera, A. Financial autonomy of local government units: Evidence from Polish rural municipalities. Lex Localis J. Local Self Gov. 2019, 17, 321-342. (In Polish) [CrossRef]

68. Dolewka, Z. Bezpieczeństwo finansowe miast wojewódzkich (Financial security provincial cities). Nierówności Społeczne Wzrost Gospod. 2014, 40,31-41. Available online: http://yadda.icm.edu.pl/yadda/element/bwmeta1. element.ekon-element-000171315171 (accessed on 18 November 2019). (In Polish).

69. Kozera, A. Stabilność finansowa gmin wiejskich w Polsce (Financial stability of rural communes in Poland). Studia I Mater. Wydziału Zarzadzania Uniw. Warsz. 2017, 2, 80-96. (In Polish) [CrossRef]

70. Coccia, M. National Debts and Government Deficits within European Monetary Union: Statistical Evidence of Economic Issues, National Research Council of Italy and Arizona State University, CocciaLab Working Paper 2018—No. 34/bis. Available online: https://arxiv.org/ftp/arxiv/papers/1806/1806.07830.pdf (accessed on 16 January 2019).

71. Eurostat Database. Available online: https://ec.europa.eu/eurostat (accessed on 26 November 2019).

72. Zadtużenie Sektora Finansów Publicznych W 1 Kwartale 2016 (The Indebtedness of the Public Finance Sector in the First Quarter of 2016); Ministry of Finance: Warsaw, Poland, 2015. Available online: https://www.cirf.gov.pl/ documents/766655/5853197/zsfp_2016_03.pdf (accessed on 16 January 2019). (In Polish)

73. Gospodarka Finansowa Jednostek Samorzadu Terytorialnego 2014 (Financial Economy of the Local Government Unit); Central Statistical Office: Warsaw, Poland, 2015. Available online: https://stat.gov.pl/obszary-tematyczne/rachunki-narodowe/statystyka-sektora-instytucji-rzadowych-isamorzadowych/gospodarka-finansowa-jednostek-samorzadu-terytorialnego-2018,5,15.html(in archives). (accessed on 26 November 2019). (In Polish)

74. Gospodarka Finansowa Jednostek Samorzadu Terytorialnego 2018 (Financial Economy of the Local Government Unit); Central Statistical Office: Warsaw, Poland, 2019. Available online: https://stat.gov.pl/obszary-tematyczne/rachunki-narodowe/statystyka-sektora-instytucji-rzadowych-isamorzadowych/gospodarka-finansowa-jednostek-samorzadu-terytorialnego-2018,5,15.html (accessed on 26 November 2019). (In Polish)

75. Strategia Zarządzania Długiem Sektora Finansów Publicznych 2015-2018 (Debt Management Strategy for the Public Finance Sector in 2015-2018); Ministry of Finance: Warsaw, Poland, 2014. Available online: http: //www.finanse.mf.gov.pl (accessed on 18 April 2019).

76. Bereźnicki, J. 2017 Najbardziej Zadłużone Gminy. Ostrowice Zbankrutowały, Jak Jest W Innych Samorzadach? (Most Indebted Municipalities. Ostrowice Went Bankrupt, How is It in Other Local Governments?). Available online: http://www.money.pl (accessed on 26 November 2019). (In Polish).

77. Standar, A. Access to EU funds vs. financial risks faced by rural municipalities of the Wielkopolskie Voivodeship. In Proceedings of the 19th International Scientific Conference, Economic Science for Rural Development 2018, Jelgava, Latvia, 9-11 May 2018; Volume 49, pp. 169-177.

78. Dylewski, M. Zadłużenie JST—Problemy nowej perspektywy finansowej UE (Local goverments' debt-problems of the new EU financial perspective). Zesz. Nauk. Uniw. Ekon. W Katowicach Studia Ekon. 2014, 198, 125-134. (In Polish)

79. Panek, T. Statystyczne Metody Wielowymiarowej Analizy Porównawczej (Statistical Methods of Multivariate Comparative Analysis); Szkoła Główna Handlowa: Warszawa, Poland, 2009. (In Polish)

80. Maher, C.S.; Nollenberger, K. Revisiting Kenneth Brown's '10-point test'. Gov. Financ. Rev. 2009, 25, 61-66.

81. McDonald, B.D. Does the charter form improve the fiscal health of counties? Public Adm. Rev. 2015, 75, 609-618. [CrossRef] 
82. Pew Charitable Trusts. State Strategies to Detect Local Fiscal Distress; Pew Charitable Trusts: Washington, DC, USA, 2016; Available online: http://www.pewtrusts.org/ \{\}/media/assets/2016/09/detecting_local_distress_ report.pdf (accessed on 27 November 2019).

83. Kieso, D.E.; Weygandt, J.J.; Warfield, T.D. Intermediate Accounting; John Wiley and Sons: New York, NY, USA, 2011; Volume 1.

84. Finkler, S.A.; Smith, D.L.; Calabrese, T.D.; Purtell, R.M. Financial Management for Public, Health, and Not-for-Profit Organizations, 5th ed.; CQ Press: Washington, DC, USA, 2017; Available online: https://www.academia.edu/38899262/FINANCIAL_MANAGEMENT_FOR_PUBLIC_HEALTH_ AND_NOT-FOR-PROFIT_ORGANIZATIONS_Fifth_Edition (accessed on 27 November 2019).

85. Groves, S.M.; Godsey, W.M.; Shulman, M.A. Financial indicators for local governments. Public Budg. Financ. 1981, 1, 5-19. [CrossRef]

86. Honadle, B.W.; Costa, J.M.; Cigler, B.A. Fiscal Health for Local Governments: An Introduction to Concepts, Practical Analysis, and Strategies; Elsevier: London, UK, 2004.

87. Hołda, A.; Pociecha, J. Probabilistyczne Metody Badania Sprawozdań Finansowych (Probabilistic Methods of Auditing Financial Statements); Wydawnictwo Uniwersytetu Ekonomicznego w Krakowie: Kraków, Poland, 2009. (In Polish)

88. Kitowski, J. Metody Dyskryminacyjne Jako Instrument Oceny Zagrożenia Upadłościa Przedsiębiorstwa (Discriminatory Methods As an Instrument for Assessing the Threat of Company Bankruptcy); Wydawnictwo Uniwersytetu Rzeszowskiego: Rzeszów, Poland, 2015. (In Polish)

89. Filipiak, B. Finanse samorzadowe. Nowe Wyzwania Bieżace i Perspektywiczne; Difin: Warszawa, Poland, 2011. (In Polish)

90. Dafflon, B.; Beer-Toth, K. Managing local public debt in transition countries: An issue of self-control. In Proceedings of the 14 th Annual Conference of the Network of Institutions and Schools of Public Administration in Central and Eastern Europe (NISPAcee), Ljubljana, Slovenia, 11-13 May 2006. [CrossRef]

91. Kata, R. Ryzyko finansowe w działalności jednostek samorządu terytorialnego-metody oceny, Zeszyty Naukowe SGGW w Warszawie. Ekon. I Organ. Gospod. Żywnościowej 2011, 97, 129-141. (In Polish)

92. Consolidated Version of the Treaty on the Functioning of the European Union, Official Journal of the European Union 26.10.2012. Available online: https://eur-lex.europa.eu/legal-content/PL/TXT/PDF/?uri=CELEX: 12012E/TXT\&from=EN (accessed on 26 November 2019).

93. Consolidated Version of the Treaty on European Union, Official Journal of the European Union 29.7.1992. Available online: https://eur-lex.europa.eu/legal-content/PL/TXT/?uri=celex\%3A11992M\%2FTXT (accessed on 26 November 2019).

94. Council Regulation (EC) No 479/2009 25.05.2009. Available online: https://eur-lex.europa.eu/LexUriServ/ LexUriServ.do?uri=OJ:L:2009:145:0001:0009:PL:PDF (accessed on 26 November 2019).

95. Regulation (EU) No 549/2013 Of The European Parliament and of The Council 21.05. Available online: https://eur-lex.europa.eu/legal-content/EN/TXT/PDF/?uri=CELEX:32013R0549\&from=pl (accessed on 26 November 2019).

96. Strategia Zarządzania Długiem Sektora Finansów Publicznych 2019-2022 (Debt Management Strategy for the Public Finance Sector in 2019-2022); Ministry of Finance: Warsaw, Poland, 2018. Available online: https: //www.gov.pl/web/finanse/strategie-zarzadzania-dlugiem (accessed on 18 April 2019).

97. Hałaburda, D.A. Zadłużenie jednostek samorządu terytorialnego w świetle nowych regulacji prawnych (Indebtedness of local governments units in the light of new law regulation). Zeszyty Naukowe SGGW w Warszawie. Ekon. I Organ. Gospod. Żywnościowej 2011, 91, 153-164. (In Polish)

(C) 2020 by the authors. Licensee MDPI, Basel, Switzerland. This article is an open access article distributed under the terms and conditions of the Creative Commons Attribution (CC BY) license (http://creativecommons.org/licenses/by/4.0/). 